\title{
Samarium Barbier Reactions of $\alpha$-Iodomethyloxazoles and Thiazoles with Aliphatic Aldehydes
}

David R. Williams, * Martin A. Berliner, Bryan W. Stroup, Partha P. Nag and Michael P. Clark

Department of Chemistry

Indiana University

Bloomington, Indiana 47405-7102

U. S. A.

\section{Supporting Information}

Experimental procedures and complete characterization data for the compounds of Schemes 1 and 2. General procedures for preparation of $\mathrm{SmI}_{2}$ and for the Barbier reactions of Table 1. Spectral data for the products of Table 1 include the ketone of 12, 15, 17, 20, 22, 24, 25, 27, 28, 30, 31, 33, 34, and 36 . 


\section{General.}

All compounds were purified by flash chromatography. Compounds that were utilized as mixtures of diastereomers or obtained with minor impurities will be clearly noted in the text.

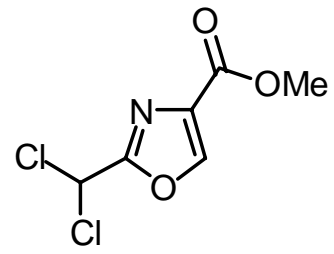

\section{2-Dichloromethyl-4,5-dihydrooxazole-4-carboxylic acid methyl ester.}

Ethyl dichloroacidimidate hydrochloride $(5.74 \mathrm{~g}, 29.8 \mathrm{mmol})$ and serine methyl ester hydrochloride (4.70 g, $30 \mathrm{mmol})$ were suspended in $\mathrm{CH}_{2} \mathrm{Cl}_{2}(60 \mathrm{~mL})$ at ambient temperature. Triethylamine $(4.15 \mathrm{~mL}, 30$ mmol) was introduced in one portion, and the resulting slurry stirred $16 \mathrm{~h}$ during which time the reaction turned pale yellow. The reaction mixture was diluted to $259 \mathrm{~mL}$ with $\mathrm{Et}_{2} \mathrm{O}$ and filtered through celite. The solids were washed with an additional $100 \mathrm{~mL} \mathrm{Et}{ }_{2} \mathrm{O}$. The filtrate was concentrated under reduced pressure to a pale yellow oil that was purified by chromatography with silica gel eluting with 2:1 hexanes:EtOAc to 1:1 hexanes:EtOAc) to provide 2-dichloromethyl-4,5-dihydrooxazole-4-carboxylic acid methyl ester (4.55 g, $21.6 \mathrm{mmol}, 72 \%)$ as a white solid: $\mathrm{R}_{\mathrm{f}}=0.7\left(1: 1\right.$ hexanes:EtOAc); mp 44-46 ${ }^{\circ} \mathrm{C} ;{ }^{1} \mathrm{H}$ NMR $\left(400 \mathrm{MHz}, \mathrm{CDCl}_{3}\right) \delta 6.27(\mathrm{~s}, 1 \mathrm{H}), 4.88(\mathrm{dd}$, $J=8.2,11.0 \mathrm{~Hz}, 1 \mathrm{H}), 4.73(\mathrm{dd}, J=8.2,8.7 \mathrm{~Hz}, 1 \mathrm{H}), 4.65(\mathrm{dd}, J=11.0,8.7 \mathrm{~Hz}, 1 \mathrm{H}), 3.80(\mathrm{~s}, 3 \mathrm{H}) ;{ }^{13} \mathrm{C} \mathrm{NMR}$ $\left(100 \mathrm{MHz}, \mathrm{CDCl}_{3}\right) \delta 170.1,164.4,71.2,68.0,60.7,52.9 ; \mathrm{IR}$ (neat) 1745, $1665 \mathrm{~cm}^{-1} ; \mathrm{MS}$ calcd for $\mathrm{C}_{6} \mathrm{H}_{8} \mathrm{NO}_{3} \mathrm{Cl}_{2}$, 211.9881, found 211.9884. Our spectroscopic data was identical with literature information for this material recently prepared from dichloroacetonitrile as reported by S. A. Hermitage, K. S. Cardwell, T. Chapman, J. W. B. Cooke and R. Newton, Organic Process Research and Development 2001, 5, 37-44. 


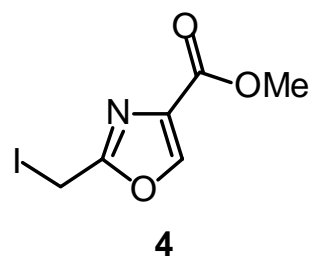

\section{2-Iodomethyloxazole-4-carboxylic acid methyl ester (4).}

2-Chloromethyloxazole-4-carboxylic acid methyl ester (5) (3.6 g, $20.7 \mathrm{mmol})$ and $\mathrm{NaI}$ (15 g) were dissolved in THF $(100 \mathrm{~mL})$ at ambient temperature. After $15 \mathrm{~min}$, the solution was diluted with EtOAc and washed with water (2 X), saturated aqueous $\mathrm{NaHSO}_{3}$ solution, brine, dried with $\mathrm{MgSO}_{4}$ and concentrated to provide an oil which crystallized upon addition of ether and hexanes yielding the 2-iodomethyloxazole 4 (4.6 g, $17.2 \mathrm{mmol}, 83 \%$ yield) as a cream-colored solid: $\mathrm{mp} 67{ }^{\circ} \mathrm{C}$; lit. $\mathrm{mp} 66^{\circ} \mathrm{C} ;{ }^{1} \mathrm{H} \mathrm{NMR}\left(400 \mathrm{MHz}, \mathrm{CDCl}_{3}\right) \delta 8.19$ (s, 1H), $4.36(\mathrm{~s}, 2 \mathrm{H}), 3.87(\mathrm{~s}, 3 \mathrm{H})$; lit. ${ }^{1} \mathrm{H}$ NMR $3.92(\mathrm{~s}, 3 \mathrm{H}), 4.4(\mathrm{~s}, 2 \mathrm{H}), 8.23(\mathrm{~S}, 1 \mathrm{H})$. Our procedure is a modification of the previous report of P. Breuilles, and D. Uguen, Tetrahedron Lett. 1998, 39, 3149-3152.

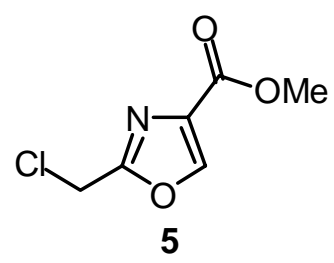

\section{2-Chloromethyloxazole-4-carboxylic acid methyl ester (5).}

The 2-dichloromethyloxazoline (4.5 g, $21.6 \mathrm{mmol})$ was dissolved in $\mathrm{CH}_{2} \mathrm{Cl}_{2}(100 \mathrm{~mL})$ and the resulting colorless solution cooled to $0{ }^{\circ} \mathrm{C}$ in an ice bath. DBU $(3.5 \mathrm{~mL}, 25.1 \mathrm{mmol})$ was then introduced in one portion, resulting in heat evolution and a slight yellowing of the solution. After one minute, the reaction was diluted to $250 \mathrm{~mL}$ with $\mathrm{Et}_{2} \mathrm{O}$ and washed with saturated $\mathrm{NH}_{4} \mathrm{Cl}$ solution, water, brine, dried with $\mathrm{MgSO}_{4}$ and concentrated to provide 5 (3.63 g, 96\% yield) as an off-white solid: $R_{f}=0.7$ (1:1 hexanes:EtOAc); ${ }^{1} \mathrm{H}$ NMR ( $400 \mathrm{MHz}$, $\left.\mathrm{CDCl}_{3}\right) \delta 8.19$ (s, 1H), $4.62(\mathrm{~s}, 2 \mathrm{H}), 3.92$ (s, 3H); ${ }^{13} \mathrm{C} \mathrm{NMR}\left(100 \mathrm{MHz}, \mathrm{CDCl}_{3}\right)$ 161.1, 159.9, 145.2, 134.0, 52.4, 35.4; IR $\left(\mathrm{CHCl}_{3}\right) 1715,1580 \mathrm{~cm}^{-1}$; MS calcd for $\mathrm{C}_{6} \mathrm{H}_{7} \mathrm{NO}_{3} \mathrm{Cl}$ 176.0114, found 176.0119. Our spectroscopic data for compound $\mathbf{5}$ is the same as described by S. A. Hermitage, K. S. Cardwell, T. Chapman, J. W. B. Cooke and R. Newton, Organic Process Research and Development 2001, 5, 37-44. 
Preparation of Aldehyde 6 of Scheme 1:
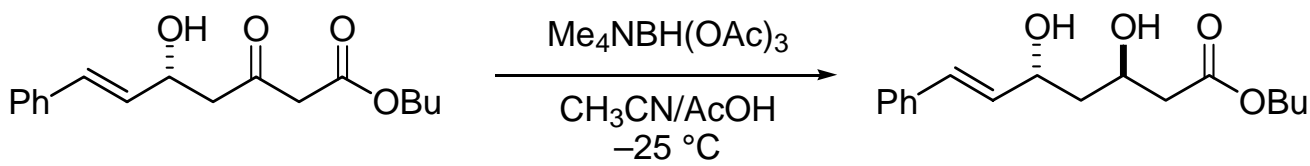

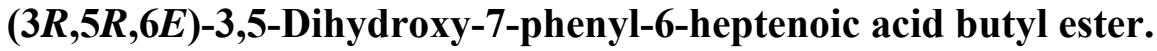

Tetramethylammonium triacetoxyborohydride (14.4 g, $55 \mathrm{mmol}, 5$ equiv) was dissolved in $35 \mathrm{~mL}$ anhydrous $\mathrm{AcOH}$ and stirred $30 \mathrm{~min}$ at ambient temperature. The starting (5R,6E)-5-hydroxy-3-oxo-7-phenyl6-heptenoic acid butyl ester (3.18 g, $10.95 \mathrm{mmol})$ was dissolved in $35 \mathrm{~mL}$ anhydrous acetonitrile and cooled to $-40{ }^{\circ} \mathrm{C}$. The borohydride solution was then transferred via cannula into the cold solution of the hydroxyketone, and the resulting slurry was maintained at $-20{ }^{\circ} \mathrm{C}$ for $36 \mathrm{~h}$. At this time, a distillation head was fitted to the reaction flask and the acetronitrile, and a majority of the acetic acid, were removed under reduced pressure $(0.5$ $\mathrm{mmHg}$ ) at a bath temperature of $\leq 25{ }^{\circ} \mathrm{C}$. The resulting liquid was dissolved in diethyl ether and the residual acetic acid was neutralized by careful portionwise addition of an aqueous $\mathrm{NaHCO}_{3}$ slurry. The layers were separated and the aqueous layer was extracted with $\mathrm{Et}_{2} \mathrm{O}$. The combined organic layers were washed with saturated $\mathrm{NaHCO}_{3}$ solution and brine, dried with $\mathrm{MgSO}_{4}$ and concentrated to a thick oil that was purified by flash chromatography with silica gel (gradient of 2:1 hexanes:EtOAc to EtOAc). A total of $2.94 \mathrm{~g}(10.1 \mathrm{mmol}$, $92 \%$ yield $)$ of diol was isolated as a colorless oil as a 92:8 ratio of syn:anti diastereomers: $R_{\mathrm{f}}=0.2(2: 1$

hexanes:EtOAc); $[\alpha]_{\mathrm{D}}{ }^{24} 6.0$ (c 0.055, $\mathrm{CHCl}_{3} ;{ }^{1} \mathrm{H}$ NMR (400 MHz, $\left.\mathrm{CDCl}_{3}\right) \delta 7.36(\mathrm{~m}, 2 \mathrm{H}), 7.30(\mathrm{~m}, 2 \mathrm{H}), 7.22$ $(\mathrm{m}, 1 \mathrm{H}), 6.64(\mathrm{dd}, J=1.2,15.9 \mathrm{~Hz}, 1 \mathrm{H}), 6.26(\mathrm{dd}, J=5.9,15.9 \mathrm{~Hz}, 1 \mathrm{H}), 4.62(\mathrm{dddd}, J=1.5,3.3,5.8,7.5 \mathrm{~Hz}$, $1 \mathrm{H}), 4.38$ (dddd, $J=3.1,4.2,7.0,9.1 \mathrm{~Hz}, 1 \mathrm{H}), 4.10(\mathrm{t}, J=6.6 \mathrm{~Hz}, 2), 2.53\left(\mathrm{~A}\right.$ of $\mathrm{ABX}, J_{\mathrm{AB}}=16.4 \mathrm{~Hz}, J_{\mathrm{AX}}=$ 9.25 Hz, 1H), $2.49\left(\mathrm{~B}\right.$ of $\left.\mathrm{ABX}, J_{\mathrm{AB}}=16.4 \mathrm{~Hz}, J_{\mathrm{BX}}=3.2 \mathrm{~Hz}, 1 \mathrm{H}\right), 1.83\left(\mathrm{ddd}, \mathrm{A}\right.$ of $\mathrm{ABXY}, J_{\mathrm{AB}}=14.4 \mathrm{~Hz}, J_{\mathrm{AX}}=$ $\left.3.4 \mathrm{~Hz}, J_{\mathrm{AY}}=9.2 \mathrm{~Hz}, 1 \mathrm{H}\right), 1.73\left(\mathrm{ddd}, \mathrm{B}\right.$ of $\left.\mathrm{ABXY}, J_{\mathrm{AB}}=14.4 \mathrm{~Hz}, J_{\mathrm{BX}}=3.0 \mathrm{~Hz}, J_{\mathrm{BY}}=7.7 \mathrm{~Hz}, 1 \mathrm{H}\right), 1.60(\mathrm{~m}$, 2H), $1.35(\mathrm{~m}, 2 \mathrm{H}), 0.91(\mathrm{t}, J=7.3 \mathrm{~Hz}, 3 \mathrm{H}) ;{ }^{13} \mathrm{C} \mathrm{NMR}\left(100 \mathrm{MHz}, \mathrm{CDCl}_{3}\right) \delta 172.8,136.6,131.8,129.8,128.5$, $127.5,126.4,69.7,65.5,64.6,42.1,41.3,3.5,19.0,13.6$; IR (neat) 3425 (br), 2959, 2933, 2873, 1729, 1449 ,

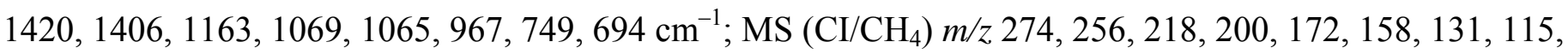
91; HRMS (CI/CH 4$)$ calcd for $\mathrm{C}_{17} \mathrm{H}_{24}, 292.1675$; found, 292.1679.
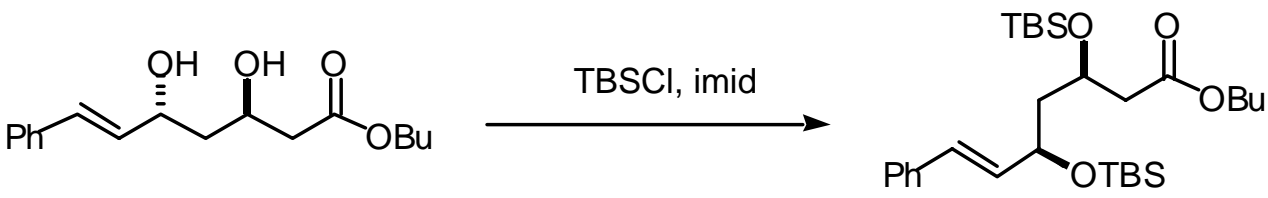
Starting diol (2.85 g, $9.75 \mathrm{mmol})$, tert-butylchlorodimethylsilane (3.67 g, $24.3 \mathrm{mmol})$ and imidazole (2.6 g, $39 \mathrm{mmol})$ were combined in $\mathrm{CH}_{2} \mathrm{Cl}_{2}(30 \mathrm{~mL})$ at ambient temperature. After $16 \mathrm{~h}$, the reaction mixture was diluted with $\mathrm{Et}_{2} \mathrm{O}$ and washed with water $(3 \mathrm{X})$, brine, dried with $\mathrm{MgSO}_{4}$ and concentrated. The resulting clear oil was purified by chromatography with silica gel (30:1 hexanes:EtOAc) to provide $4.3 \mathrm{~g}(8.3 \mathrm{mmol}, 85 \%$ yield) of the corresponding bis(silyl) ether as a colorless oil: $\mathrm{R}_{\mathrm{f}}=0.6\left(10: 1\right.$ hexanes:EtOAc); $[\alpha]_{\mathrm{D}}{ }^{24} 16(\mathrm{c} 0.015$, $\left.\mathrm{CH}_{2} \mathrm{Cl}_{2}\right) ;{ }^{1} \mathrm{H}$ NMR $\left(400 \mathrm{MHz}, \mathrm{CDCl}_{3}\right) \delta 7.4-7.25(\mathrm{~m}, 5 \mathrm{H}), 6.45(\mathrm{~d}, J=15.9 \mathrm{~Hz}, 1 \mathrm{H}), 6.12(\mathrm{dd}, J=15.9,7.3 \mathrm{~Hz}$, $1 \mathrm{H}), 4.36(\mathrm{ddt}, J=1.0,5.2,7.3 \mathrm{~Hz}, 1 \mathrm{H}), 4.27(\mathrm{dq}, J=7.0,5.9 \mathrm{~Hz}, 1 \mathrm{H}), 4.04\left(\mathrm{dt}, \mathrm{A}\right.$ of $\mathrm{ABX}^{2}, J_{\mathrm{AB}}=10.4 \mathrm{~Hz}, J_{\mathrm{AX}}$ $=6.9 \mathrm{~Hz}, 1 \mathrm{H}), 4.02\left(\mathrm{dt}, \mathrm{B}\right.$ of $\left.\mathrm{ABX}^{2}, J_{\mathrm{BA}}=10.4 \mathrm{~Hz}, J_{\mathrm{BC}}=7.0 \mathrm{~Hz}, 1 \mathrm{H}\right), 2.53\left(\mathrm{dd}, \mathrm{A}\right.$ of $\mathrm{ABX}, J_{\mathrm{AB}}=14.5 \mathrm{~Hz}, J_{\mathrm{AX}}$ $=5.2 \mathrm{~Hz}, 1 \mathrm{H}), 2.46\left(\mathrm{dd}, \mathrm{B}\right.$ of $\left.\mathrm{ABX}, J_{\mathrm{BA}}=14.5 \mathrm{~Hz}, J_{\mathrm{BX}}=7.2 \mathrm{~Hz}, 1 \mathrm{H}\right), 1.82\left(\mathrm{ddd}, \mathrm{A}\right.$ of $\mathrm{ABXY}, J_{\mathrm{AB}}=13.9 \mathrm{~Hz}$, $\left.J_{\mathrm{AX}}=6.2 \mathrm{~Hz}, J_{\mathrm{AY}}=7.5 \mathrm{~Hz}, 1 \mathrm{H}\right), 1.74\left(\mathrm{dt}, \mathrm{B}\right.$ of $\left.\mathrm{ABXY}, J_{\mathrm{BA}}=13.9 \mathrm{~Hz}, J_{\mathrm{BC}}=J_{\mathrm{BD}}=5.5 \mathrm{~Hz}, 1 \mathrm{H}\right), 1.57(\mathrm{~m}, 2 \mathrm{H})$, 1.35 (m, 2H), 0.90 (t, J=7.0 Hz 3H), 0.89 (s, 9H), 0.85 (s, 9H), 0.073 (s, 3H), 0.070 (s, 3H), 0.029 (s, 3H), $0.023(\mathrm{~s}, 3 \mathrm{H}) ;{ }^{13} \mathrm{C} \mathrm{NMR}\left(100 \mathrm{MHz}, \mathrm{CDCl}_{3}\right) \delta 171.47,136.86,133.13,129.58,128.55,127.48,126.39,71.31$, $67.10,64.23,46.74,43.66,30.62,25.93,25.89,25.79,19.15,18.16,17.97,13.70,-3.68,-4.31,-4.49,-4.57$; IR $\left(\mathrm{cm}^{-1}\right)$ 2957, 2930, 2895, 2887, 2856, 1737, 1253, 1163, 1093, 1076, 966; MS (CI/CH $)_{4}$ m/z 75, 101, 157 , 201, 231, 272, 321, 388, 463, 505; HRMS $\left(\mathrm{CI} / \mathrm{CH}_{4}\right)$ for $\mathrm{C}_{28} \mathrm{H}_{49} \mathrm{O}_{4} \mathrm{Si}_{2}\left(\mathrm{M}-\mathrm{CH}_{3}\right)^{+}$, calculated: 505.3169; found: 505. 3183 .
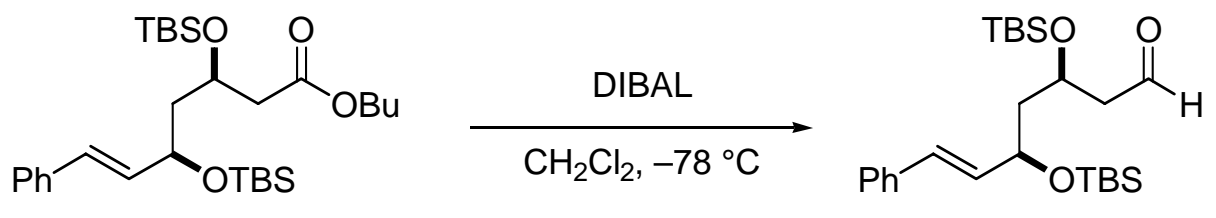

6

\section{(3R,5R,6E)-3,5-Bis(tert-butyldimethylsilyloxy)-7-phenyl-6-heptenal.}

Butyl ester $(15.0 \mathrm{~g}, 28.8 \mathrm{mmol})$ was dissolved in $\mathrm{CH}_{2} \mathrm{Cl}_{2}(200 \mathrm{~mL})$ and cooled to $-78{ }^{\circ} \mathrm{C}$ in a dry iceacetone bath. A solution of diisobutylaluminum hydride (1.0 M in hexanes, $32 \mathrm{~mL}, 32 \mathrm{mmol})$ was introduced in a slow stream and the reaction maintained at $-78^{\circ} \mathrm{C}$ until the reduction was complete (15 min). Acetone (2 $\mathrm{mL}$ ) was then introduced to quench any unreacted DIBAL and the solution warmed to ambient temperature. Addition of a half-saturated solution of Rochelle's salt to the reaction resulted in an emulsion that was stirred vigorously until the phases separated upon cessation of stirring ( $2 \mathrm{hrs}$ ). The organic layer was removed, washed 
with brine, dried with $\mathrm{MgSO}_{4}$ and concentrated to an oil that was purified by chromatography with silica gel (15:1 hexanes:EtOAc). Aldehyde product 6 was isolated as a clear, colorless oil (11.94 g, 92\% yield): $\mathrm{R}_{\mathrm{f}}=$ 0.55 (10:1 hexanes:EtOAc); $[\alpha]_{\mathrm{D}}{ }^{25}+21\left(\mathrm{c} 0.031, \mathrm{CH}_{2} \mathrm{Cl}_{2}\right) ;{ }^{1} \mathrm{H}$ NMR $\left(400 \mathrm{MHz}, \mathrm{CDCl}_{3}\right) \delta 9.78(\mathrm{dd}, J=2.2,3.0$ Hz, 1H), 7.4-7.2 (m, 5H), $6.44(\mathrm{~d}, J=15.9 \mathrm{~Hz}, 1 \mathrm{H}), 6.11(\mathrm{dd}, J=15.9,7.5 \mathrm{~Hz}, 1 \mathrm{H}), 4.34(\mathrm{~m}, 2 \mathrm{H}), 2.61$ (ddd, A of $\left.\mathrm{ABXY}, J_{\mathrm{AB}}=15.7 \mathrm{~Hz}, J_{\mathrm{AX}}=2.0 \mathrm{~Hz}, J_{\mathrm{AY}}=4.8 \mathrm{~Hz}, 1 \mathrm{H}\right), 2.54\left(\mathrm{ddd}, \mathrm{B}\right.$ of $\mathrm{ABXY}, J_{\mathrm{BA}}=15.7 \mathrm{~Hz}, J_{\mathrm{BX}}=3.0$ $\left.\mathrm{Hz}, J_{\mathrm{BY}}=6.5 \mathrm{~Hz}, 1 \mathrm{H}\right), 1.85\left(\mathrm{dt}, \mathrm{A}\right.$ of $\left.\mathrm{ABXY}, J_{\mathrm{AB}}=13.6 \mathrm{~Hz}, J_{\mathrm{AX}}=J_{\mathrm{AY}}=6.6 \mathrm{~Hz}, 1 \mathrm{H}\right), 1.82(\mathrm{dt}, \mathrm{B}$ of $\mathrm{ABXY}$, $\left.J_{\mathrm{BA}}=13.6 \mathrm{~Hz}, J_{\mathrm{BC}}=J_{\mathrm{BD}}=5.7 \mathrm{~Hz}, 1 \mathrm{H}\right), 0.88(\mathrm{~s}, 9 \mathrm{H}), 0.86(\mathrm{~s}, 9 \mathrm{H}), 0.87(\mathrm{~s}, 3 \mathrm{H}), 0.065(\mathrm{~s}, 3 \mathrm{H}), 0.048(\mathrm{~s}, 3 \mathrm{H})$, 0.024 (s, 3H); ${ }^{13} \mathrm{C}$ NMR (100 MHz, $\left.\mathrm{CDCl}_{3}\right) \delta 202.0,136.6,132.7,129.9,128.6,127.6,126.4,71.3,65.8,51.6$, $46.8,25.9,25.9,25.8,18.2,18.0,-3.7,-4.2,-4.4$; IR (neat) $2955,2930,2887,2856,1726,1471,1462,1255$,

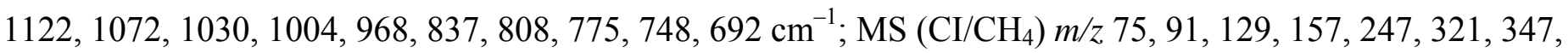
391, 430; HRMS (CI/CH4) calcd for $\mathrm{C}_{25} \mathrm{H}_{42} \mathrm{O}_{2} \mathrm{Si}_{2}\left(\mathrm{M}-\mathrm{H}_{2} \mathrm{O}\right)^{+}$430.2723, found 430.2725.

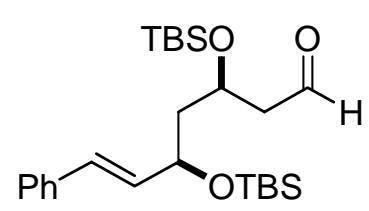

6

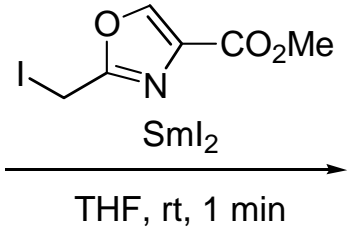

THF, rt, 1 min

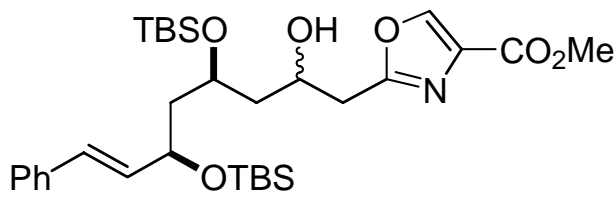

7

\section{2-[(2RS,4R,6R,7E)-4,6-Bis(tert-butyldimethylsilyloxy)-2-hydroxy-8-phenyl-7-octenyl]-oxazole-4-} carboxylic acid methyl ester (7).

A solution of $\mathrm{SmI}_{2}$ in THF was prepared by slow addition of $\mathrm{CH}_{2} \mathrm{I}_{2}(807 \mu \mathrm{L}, 10 \mathrm{mmol})$ to a suspension of Sm powder $(1.51 \mathrm{~g}, 10.1 \mathrm{mmol})$ in anhydrous, degassed THF (40 mL) maintained at ambient temperature with a water bath. This mixture was stirred 2-3 h until a majority of the Sm metal had been consumed. In another flask, aldehyde 6 (1.79 g, $4.0 \mathrm{mmol})$ and oxazole iodide 4 (1.07 g, $4.0 \mathrm{mmol})$ were dissolved in anhydrous, degassed THF ( $5 \mathrm{~mL})$ and this mixture was introduced via cannula to the stirring solution of $\mathrm{SmI}_{2}$ over 2 min. Once the addition was complete, the reaction mixture was diluted with $\mathrm{Et}_{2} \mathrm{O}(40 \mathrm{~mL})$ and a saturated aqueous solution of $\mathrm{Na} \cdot \mathrm{K}$ tartrate $(100 \mathrm{~mL})$ and the resulting emulsion stirred vigorously until the organic phase separated on cessation of stirring. The layers were separated and the aqueous layer extracted twice with 1:1 hexanes:EtOAc. The combined organic layers were washed with brine, dried with $\mathrm{MgSO}_{4}$ and concentrated in the absence of light to a pale yellow oil that was purified by chromatography with silica gel (eluting with 4:1 hexanes:EtOAc to 2:1 hexanes:EtOAc). The resulting light yellow oil (7, 1.53 g, 66\% yield; 
50:50 mixture of diastereomers at $\mathrm{C} 33$ ) rapidly darkens to an orange-red oil on exposure to light and was usually employed directly in the next reaction without delay; $\mathrm{R}_{\mathrm{f}}=0.6(2: 1$ hexanes:EtOAc). The following data are reported for the diastereomeric mixture obtained in this reaction: $[\alpha]_{\mathrm{D}}{ }^{25}+2.0\left(\mathrm{c} 0.018, \mathrm{CH}_{2} \mathrm{Cl}_{2}\right) ;{ }^{1} \mathrm{H} \mathrm{NMR}$ $\left(400 \mathrm{MHz}, \mathrm{CDCl}_{3}\right) \delta 8.13(\mathrm{~s}, 0.5 \mathrm{H}), 8.10(\mathrm{~s}, 0.5 \mathrm{H}), 7.35-7.20(\mathrm{~m}, 5 \mathrm{H}), 6.42(\mathrm{~d}, J=16.9 \mathrm{~Hz}, 0.5 \mathrm{H}), 6.40(\mathrm{~d}, J=$ $16.9 \mathrm{~Hz}, 0.5 \mathrm{H}), 6.09(\mathrm{dd}, J=16.9,7.3 \mathrm{~Hz}, 0.5 \mathrm{H}), 6.08(\mathrm{dd}, J=16.9,7.3 \mathrm{~Hz}, 0.5 \mathrm{H}), 4.45(\mathrm{~m}, 0.5 \mathrm{H}), 4.25(\mathrm{~m}$, 1.5H), $4.13(\mathrm{~m}, 0.5 \mathrm{H}), 3.98(\mathrm{~m}, 0.5 \mathrm{H}), 3.88(\mathrm{~s}, 3 \mathrm{H}), 3.0-2.85(\mathrm{~m}, 4 \mathrm{H}), 0.86(\mathrm{br} \mathrm{s}, 18 \mathrm{H}), 0.078(\mathrm{~s}, 1.5 \mathrm{H}), 0.078$ $(\mathrm{s}, 1.5 \mathrm{H}), 0.066(\mathrm{~s}, 3 \mathrm{H}), 0.050(\mathrm{~s}, 1.5 \mathrm{H}), 0.046(\mathrm{~s}, 1.5 \mathrm{H}), 0.014(\mathrm{~s}, 1.5 \mathrm{H}), 0.007(\mathrm{~s}, 1.5 \mathrm{H}) ;{ }^{13} \mathrm{C} \mathrm{NMR}(100 \mathrm{MHz}$ $\left.\mathrm{CDCl}_{3}\right) \delta 163.4,163.3,161.6,161.6,143.9,136.6,136.6,133.2,133.1,132.6,132.4,130.1,129.9,128.6,127.6$, $126.4,71.5,69.8,68.9,68.0,66.5,52.1,46.9,44.9,43.4,41.5,36.4,36.1,25.9,25.8,25.8,18.2,17.9,-3.8,-$ $3.9,-4.0,-4.4,-4.5,-4.6,-4.6,-4.7$; IR (neat) 3488 (br), 2953, 2930, 2857, 1740, 1586, 1472, 1462, 1439,

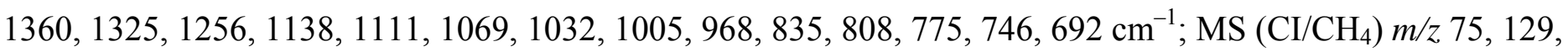
167, 247, 270, 308, 400, 457, 532; HRMS (CI/CH4) calcd for $\mathrm{C}_{27} \mathrm{H}_{42} \mathrm{NO}_{6} \mathrm{Si}_{2}\left(\mathrm{M}-\mathrm{C}_{4} \mathrm{H}_{9}\right)^{+}$532.2550, found 532.2537 .

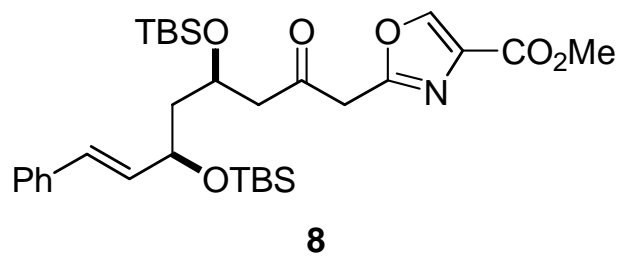

\section{2-[(4R,6R,7E)-4,6-Bis(tert-butyldimethylsilyloxy)-2-oxo-8-phenyl-7-octenyl]-oxazole-4-carboxylic acid} methyl ester (8).

Trifluoroacetic anhydride $(310 \mu \mathrm{L}, 2.20 \mathrm{mmol})$ was dissolved in $\mathrm{CH}_{2} \mathrm{Cl}_{2}(2 \mathrm{~mL})$ and cooled to $-78{ }^{\circ} \mathrm{C}$ in a dry ice-acetone bath. A solution of dimethylsulfoxide $(235 \mu \mathrm{L}, 3.3 \mathrm{mmol})$ in $\mathrm{CH}_{2} \mathrm{Cl}_{2}(2 \mathrm{~mL})$ was introduced dropwise, and the resulting slurry maintained at $-78^{\circ} \mathrm{C}$ for $15 \mathrm{~min}$. A solution of alcohol 7 (650 $\mathrm{mg}, 1.10$ mmol) in $\mathrm{CH}_{2} \mathrm{Cl}_{2}(3 \mathrm{~mL})$ was then added dropwise to the TFAA/DMSO adduct, and the resulting yellow slurry stirred another $30 \mathrm{~min}$ at $-78{ }^{\circ} \mathrm{C}$. At this time, triethylamine $(760 \mu \mathrm{L}, 5.5 \mathrm{mmol})$ was added in one portion and the reaction gradually warmed to $0{ }^{\circ} \mathrm{C}$ before being diluted with $\mathrm{Et}_{2} \mathrm{O}$ and poured into a separatory funnel. The organic layer was washed with water, aqueous $\mathrm{NH}_{4} \mathrm{Cl}$ solution $(2 \mathrm{X})$, water, brine, dried with $\mathrm{MgSO}_{4}$ and concentrated in the absence of light to a light yellow oil. Purification by flash chromatography with silica gel (eluting with a gradient of 3:1 hexanes:EtOAc to 2:1 hexanes:EtOAc) provided $\beta$-ketooxazole 8 as a thick 
yellow oil (540 mg, $919 \mu \mathrm{mol}, 84 \%$ yield) that was protected from light during routine handling: $\mathrm{R}_{\mathrm{f}}=0.70(2: 1$ hexanes:EtOAc); $[\alpha]_{\mathrm{D}}{ }^{25}+8.1\left(\mathrm{c} 0.062, \mathrm{CHCl}_{3}\right) ;{ }^{1} \mathrm{H} \mathrm{NMR}\left(400 \mathrm{MHz}, \mathrm{CDCl}_{3}\right) \delta 8.16(\mathrm{~s}, 1 \mathrm{H}), 7.40-7.20(\mathrm{~m}, 5 \mathrm{H})$, $6.44(\mathrm{~d}, J=15.9 \mathrm{~Hz}, 1 \mathrm{H}), 6.09(\mathrm{dd}, J=15.9 \mathrm{~Hz}, 7.4 \mathrm{~Hz}, 1 \mathrm{H}), 4.33(\mathrm{~m}, 2 \mathrm{H}), 3.99$ (d, A of AB, $J=17.4 \mathrm{~Hz}, 1 \mathrm{H})$, $3.91(\mathrm{~d}, \mathrm{~B}$ of $\mathrm{AB}, J=17.4 \mathrm{~Hz}, 1 \mathrm{H}), 3.89(\mathrm{~s}, 3 \mathrm{H}), 2.71(\mathrm{~d}, J=5.8 \mathrm{~Hz}, 2 \mathrm{H}), 1.81\left(\mathrm{dt}, \mathrm{A}\right.$ of $\mathrm{ABX}^{2}, J_{\mathrm{AB}}=14.0 \mathrm{~Hz}$, $\left.J_{\mathrm{AX}}=7.0 \mathrm{~Hz}, 1 \mathrm{H}\right), 1.74\left(\mathrm{dt}, \mathrm{B}\right.$ of $\left.\mathrm{ABX}^{2}, J_{\mathrm{BA}}=14.0 \mathrm{~Hz}, J_{\mathrm{BX}}=5.3 \mathrm{~Hz}, 1 \mathrm{H}\right), 0.87(\mathrm{~s}, 9 \mathrm{H}), 0.85(\mathrm{~s}, 9 \mathrm{H}), 0.07(\mathrm{~s}$, 3H), 0.05 (s, 3H), 0.02 (s, 3H), 0.01 (s, 3H); ${ }^{13} \mathrm{C} \mathrm{NMR} \mathrm{(100} \mathrm{MHz,} \mathrm{CDCl} 3$ ) $\delta 201.3,161.4,158.9,144.7,136.7$, $133.5,132.8,129.8,128.6,128.6,127.6,126.4,71.3,66.6,52.2,50.6,46.3,43.8,25.9,25.9,25.8,18.2,18.0,-$ $3.8,-4.4,-4.5,-4.6$; IR (neat) 2955, 2930, 2895, 2857, 1748, 1730, 1586, 1325, 1254, 1134, 1113, 1092, 1072 ,

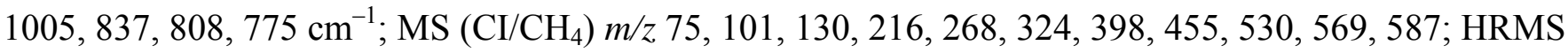
$\left(\mathrm{CI} / \mathrm{CH}_{4}\right)$ calcd for $\mathrm{C}_{31} \mathrm{H}_{47} \mathrm{NO}_{5} \mathrm{Si}_{2}\left(\mathrm{M}-\mathrm{H}_{2} \mathrm{O}\right)^{+}$569.2993, found 569.2979.

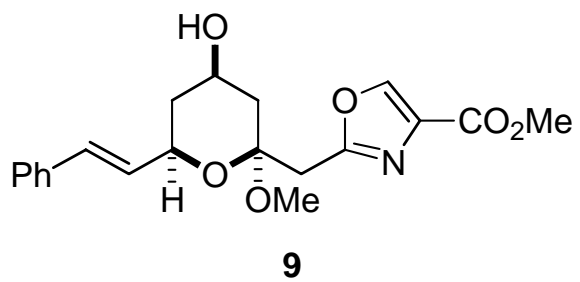

\section{2-(2S,4R,6R(1E))-4-Hydroxy-2-methoxy-6-(2-phenylethenyl)tetrahydro-2H-pyranylmethyl)oxazole-4-} carboxylic acid methyl ester (9).

Bis(silyl) ether $8(540 \mathrm{mg}, 919 \mu \mathrm{mol})$ was dissolved in $\mathrm{MeOH}(15 \mathrm{~mL})$ containing a catalytic amount of camphorsulfonic acid (10 mg). After stirring $16 \mathrm{~h}$ at ambient temperature, the acid was neutralized by addition of solid $\mathrm{NaHCO}_{3}$ followed by removal of the volatiles by rotary evaporation and partitioning of the light orange residue between EtOAc and water. The aqueous layer was extracted twice with EtOAc, and the combined organic layers washed with brine, dried with $\mathrm{MgSO}_{4}$ and concentrated to a light yellow oil that was purified by flash chromatography with silica gel (eluting with a gradient of 1:1 hexanes;EtOAc to 1:2 hexanes:EtOAc). The resulting viscous oil was redissolved in $\mathrm{CH}_{2} \mathrm{Cl}_{2}$ and concentrated to a pale yellow foam that solidifed under full vacuum $(0.5 \mathrm{mmHG})$. A total of $296 \mathrm{mg}(792 \mu \mathrm{mol}, 86 \%$ yield of cyclic hemiacetal 9 was isolated as a single diastereomer: $\mathrm{R}_{\mathrm{f}}=0.25\left(1: 2\right.$ hexanes:EtOAc); mp $45{ }^{\circ} \mathrm{C} ;[\alpha]_{\mathrm{D}}{ }^{25}-16.5\left(\mathrm{c} 0.094, \mathrm{CH}_{2} \mathrm{Cl}_{2}\right) ;{ }^{1} \mathrm{H}$ NMR $(500$ $\left.\mathrm{MHz}, \mathrm{CDCl}_{3}\right) \delta 8.19(\mathrm{~s}, 1 \mathrm{H}), 7.38(\mathrm{~m}, 2 \mathrm{H}), 7.31(\mathrm{~m}, 2 \mathrm{H}), 7.23(\mathrm{~m}, 1 \mathrm{H}), 6.60(\mathrm{~d}, J=15.9 \mathrm{~Hz}, 1 \mathrm{H}), 6.18(\mathrm{dd}, J=$ 15.9, $6.2 \mathrm{~Hz}, 1 \mathrm{H}), 4.22(\mathrm{dddd}, J=1.2,2.1,6.2,11.6 \mathrm{~Hz}, 1 \mathrm{H}), 4.11(\mathrm{tt}, J=4.7,11.1 \mathrm{~Hz}, 1 \mathrm{H}), 3.90(\mathrm{~s}, 3 \mathrm{H}), 3.38$ (d, A of AB, $J=14.8 \mathrm{~Hz}, 1 \mathrm{H}), 3.34(\mathrm{~s}, 3 \mathrm{H}), 3.13(\mathrm{~d}, \mathrm{~B}$ of $\mathrm{AB}, J=14.8 \mathrm{~Hz}, 1 \mathrm{H}), 2.17$ (ddd, $J=1.8,4.7,12.6 \mathrm{~Hz}$, 
1H), 2.07 (ddt, $J=4.3,12.3,2.1 \mathrm{~Hz}, 1 \mathrm{H}), 1.53(\mathrm{dd}, J=11.2,12.8 \mathrm{~Hz}, 1 \mathrm{H}), 1.50$ (br s, $-\mathrm{OH}, 1 \mathrm{H}), 1.33$ (dt, $J=$ 11.6, $11.8 \mathrm{~Hz}, 1 \mathrm{H}) ;{ }^{13} \mathrm{C} \mathrm{NMR}\left(100 \mathrm{MHz}, \mathrm{CDCl}_{3}\right) \delta 161.5,161.0,144.3,136.4,133.3,130.7,128.7,128.5$, 127.7, 126.4, 99.8, 70.3, 64.2, 52.0, 48.0, 42.3, 40.1, 35.6; IR (neat) 3407 (br), 2951, 1740, 1584, 1449, 1439, 1329, 1221, 1200, 1148, 1113, 1030, 1005, 958, 766, 748, $694 \mathrm{~cm}^{-1}$; MS (CI/CH $) \mathrm{m} / \mathrm{z}$ 81, 100, 115, 141, 155, 183, 198, 254, 282, 324, 341; HRMS (CI/CH$)$ calcd for $\mathrm{C}_{19} \mathrm{H}_{19} \mathrm{NO}_{5}\left(\mathrm{M}-\mathrm{CH}{ }_{4} \mathrm{O}\right)^{+}$341.1263, found 341.1262 .

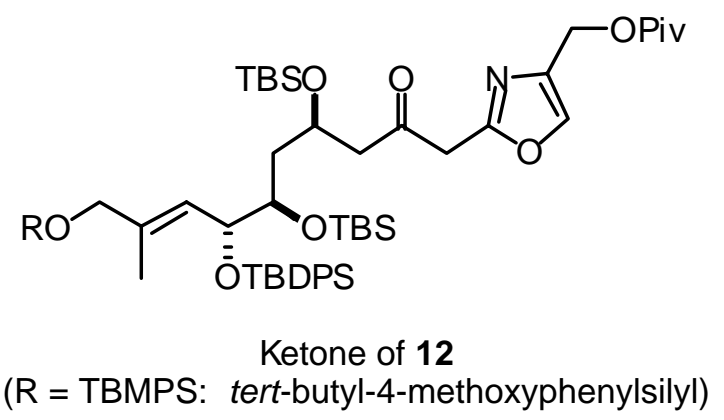

Preparation and Characterization of the Ketone Derived from Diastereomeric Alcohols 12: A solution of $\mathrm{SmI}_{2}$ in THF was prepared by addition of $\mathrm{CH}_{2} \mathrm{I}_{2}(0.09 \mathrm{~mL}, 1.08 \mathrm{mmol})$ to a suspension of $\mathrm{Sm}^{\circ}$ powder $(0.17 \mathrm{~g}$, $1.08 \mathrm{mmol})$ in anhydrous, degassed THF $(2 \mathrm{~mL})$. This mixture was stirred in the dark for $2 \mathrm{~h}$ at room temperature. A pre-mixed solution of aldehyde $11(0.24 \mathrm{mg}, 0.27 \mathrm{mmol})$ and oxazole iodide $10(0.10 \mathrm{~g}, 0.30$ mmol) in degassed THF ( $1 \mathrm{~mL})$ was introduced dropwise to the stirring solution of $\mathrm{SmI}_{2}$. After stirring for 15 min at room temperature, the reaction mixture was diluted with ether $(50 \mathrm{~mL})$ and brine $(80 \mathrm{~mL})$. The biphasic mixture was separated. The aqueous phase was extracted with ether $(30 \mathrm{~mL})$. The combined organic phases were dried $\left(\mathrm{MgSO}_{4}\right)$, filtered and concentrated in vacuo. The residue was purified by flash chromatography (15 $\mathrm{g} \mathrm{SiO}_{2}, 8 \% \mathrm{EtOAc} /$ hexanes) to afford $220 \mathrm{mg}(76 \%)$ of the $\beta$-hydroxyoxazole 12 (95\% purity) as a 1:1 mixture of diastereomers. The alcohols 12 were fully characterized upon oxidation to the corresponding ketone.

To a cold $\left(-78^{\circ} \mathrm{C}\right)$ solution of trifluoroacetic anhydride $(0.06 \mathrm{~mL}, 0.44 \mathrm{mmol})$ in $\mathrm{CH}_{2} \mathrm{Cl}_{2}(2 \mathrm{~mL})$ was added dimethylsulfoxide $(0.06 \mathrm{~mL}, 0.88 \mathrm{mmol})$. The resulting slurry was maintained at $-78{ }^{\circ} \mathrm{C}$ for $15 \mathrm{~min}$. A solution of the $\beta$-hydroxyoxazole $12(0.19 \mathrm{~g}, 0.17 \mathrm{mmol})$ in $\mathrm{CH}_{2} \mathrm{Cl}_{2}(0.5 \mathrm{~mL})$ was then added dropwise to the TFAA/DMSO adduct, and the resulting yellow slurry stirred another $20 \mathrm{~min}$ at $-78{ }^{\circ} \mathrm{C}$. At this time triethylamine $(0.20 \mathrm{~mL}, 1.42 \mathrm{mmol})$ was added in one portion and the reaction was gradually warmed to -30 ${ }^{\circ} \mathrm{C}$. The solution was diluted with ether $(80 \mathrm{~mL})$ and then washed with aqueous saturated $\mathrm{NaHCO}_{3}\left(2 \mathrm{X}_{50}\right.$ $\mathrm{mL})$. The combined aqueous phases were back extracted with ether $(40 \mathrm{~mL})$. The combined organic phases 
were dried $\left(\mathrm{MgSO}_{4}\right)$, filtered and concentrated in vacuo. The residue was purified by flash chromatography (10 $\mathrm{g} \mathrm{SiO}_{2}, 8 \% \mathrm{EtOAc} /$ hexanes) to afford $134 \mathrm{mg}(71 \%)$ of the $\beta$-ketooxazole of $12: \mathrm{R}_{\mathrm{f}}=0.43$ in $20 \%$

EtOAc/hexanes; ${ }^{1} \mathrm{H}$ NMR (400 MHz, $\left.\mathrm{CDCl}_{3}\right) \delta 7.72-7.58(\mathrm{~m}, 6 \mathrm{H}), 7.52(\mathrm{~s}, 1 \mathrm{H}), 7.43-7.22(\mathrm{~m}, 9 \mathrm{H}), 5.86(\mathrm{dd}, \mathrm{J}$ $=7.2,6.8 \mathrm{~Hz}, 1 \mathrm{H}), 5.00(\mathrm{~s}, 1 \mathrm{H}), 4.99(\mathrm{~s}, 1 \mathrm{H}), 4.34-4.31(\mathrm{~m}, 2 \mathrm{H}), 4.03-3.80(\mathrm{~m}, 4 \mathrm{H}), 3.55(\mathrm{~s}, 1.5 \mathrm{H}), 3.54(\mathrm{~s}$, 1.5H), $3.51(\mathrm{dd}, J=12.0,5.2 \mathrm{~Hz}, 1 \mathrm{H}), 2.74-2.66(\mathrm{~m}, 2 \mathrm{H}), 2.17-2.04(\mathrm{~m}, 1 \mathrm{H}), 1.67-1.50(\mathrm{~m}, 3 \mathrm{H}), 1.20(\mathrm{~s}, 9 \mathrm{H})$, $1.06(\mathrm{~d}, J=10.4 \mathrm{~Hz}, 3 \mathrm{H}), 1.03(\mathrm{~s}, 9 \mathrm{H}), 0.95(\mathrm{~s}, 9 \mathrm{H}), 0.87(\mathrm{~s}, 4.5 \mathrm{H}), 0.86(\mathrm{~s}, 4.5 \mathrm{H}), 0.75(\mathrm{~s}, 4.5 \mathrm{H}), 0.73(\mathrm{~s}, 4.5 \mathrm{H})$, $0.13(\mathrm{~s}, 1.5 \mathrm{H}), 0.11(\mathrm{~s}, 1.5 \mathrm{H}), 0.05(\mathrm{~s}, 1.5 \mathrm{H}), 0.04(\mathrm{~s}, 1.5 \mathrm{H}),-0.04(\mathrm{~s}, 3 \mathrm{H}),-0.24(\mathrm{~s}, 3 \mathrm{H})$; IR (neat) 3080, 1730; $1650,1575 \mathrm{~cm}^{-1}$; HRMS $\left(\mathrm{CI} / \mathrm{CH}_{4}\right)$ calcd for $\mathrm{C}_{55} \mathrm{H}_{84} \mathrm{NO}_{9} \mathrm{Si}_{4}\left(\mathrm{M}-\mathrm{C}_{4} \mathrm{H}_{9}\right)^{+}$.

\section{General Procedure for Preparation of Heterocyclic Iodides from their Corresponding Alcohols.}

To a cold $\left(0^{\circ} \mathrm{C}\right)$ solution of triphenylphosphine $(0.58 \mathrm{~g}, 0.221 \mathrm{mmol})$ and imidazole $(30.0 \mathrm{mg}, 0.440$ $\mathrm{mmol})$ in $\mathrm{CH}_{2} \mathrm{Cl}_{2}(1.0 \mathrm{~mL})$ was added iodine $(56.0 \mathrm{mg}, 0.220 \mathrm{mmol})$. The mixture was stirred at $0{ }^{\circ} \mathrm{C}$ for 30 min. The alcohol $(0.067 \mathrm{mmol})$ was added as a solution in $\mathrm{CH}_{2} \mathrm{Cl}_{2}(0.4 \mathrm{~mL})$ into the reaction mixture. After 15 min, the mixture was diluted with $\mathrm{CH}_{2} \mathrm{Cl}_{2}(\sim 30 \mathrm{~mL})$ and washed with $\mathrm{H}_{2} \mathrm{O}(2 \mathrm{X} 25 \mathrm{~mL})$. The combined aqueous phases were extracted with $\mathrm{CH}_{2} \mathrm{Cl}_{2}(15 \mathrm{~mL})$, and the combined organic phases were dried $\left(\mathrm{MgSO}_{4}\right)$, filtered and concentrated in vacuo. The crude residue was purified by flash chromatography using silica gel to afford the desired iodide (75-95\% yield).

\section{General Procedure for Preparation of Samarium Diiodide.}

To improve the purity of commercial 1,2-diiodoethane, the crude reagent was dissolved in ether and washed with saturated aqueous $\mathrm{Na}_{2} \mathrm{SO}_{3}$. The ether solution was dried over anhydrous $\mathrm{MgSO}_{4}$, filtered and concentrated. The resulting white solid was protected from light and dried for at least one hour under high vacuum prior to use. A $250 \mathrm{~mL}$ flame-dried Schlenk flask was charged with Sm metal (1.26g; $8.38 \mathrm{mmol})$. The flask was evacuated and purged with argon three times, and protected from light. The 1,2-diiodoethane (1.18 g; $4.19 \mathrm{mmol})$ in dry, deoxygenated THF (42 mL) was added rapidly via cannula with vigorous stirring. The suspension was stirred in the dark at $22{ }^{\circ} \mathrm{C}$ for at least $5 \mathrm{~h}$ to produce a dark blue solution of samarium diiodide $(0.1 \underline{\mathrm{M}}$ in THF). This solution was freshly prepared for the reduction/metalation of $0.863 \mathrm{mmol}$ of the starting $\alpha$-iodomethyl heterocycles of Table 1 . 
General Procedure for Samarium Diiodide-Barbier Reactions of Iodomethyl Heterocycles with Aldehydes of Table 1.

A general procedure was utilized for the samarium Barbier reactions of Table 1. A mixture of starting aldehyde $(0.86 \mathrm{mmol})$ and freshly purified heterocyclic iodide $(0.86 \mathrm{mmol})$ was dissolved in anhydrous, deoxygenated THF $(8.6 \mathrm{~mL})$. This solution was added via cannulation into a flask containing a dark blue solution of freshly prepared $\mathrm{SmI}_{2}(0.1 \underline{\mathrm{M}}$ in THF), which was estimated to contain $3.0 \mathrm{mmol}$ of reagent, and stirring was then continued for $5 \mathrm{~min}$. If the reaction mixture failed to maintain a dark blue color, and starting reactants persisted as indicated by TLC, then an additional amount of $\mathrm{SmI}_{2}$ solution was introduced. Reactions were quenched by the introduction of saturated aqueous potassium sodium tartrate and subsequent stirring for $30 \mathrm{~min}$. After dilution with $\mathrm{Et}_{2} \mathrm{O}(20 \mathrm{~mL})$, the layers were separated, and the aqueous phase was extracted with $\mathrm{Et}_{2} \mathrm{O}(3 \mathrm{X} 10 \mathrm{~mL})$. Combined organic phases were washed with brine, dried $\left(\mathrm{MgSO}_{4}\right)$, filtered, and concentrated in vacuo. The resulting oil was purified by flash chromatography on silica gel with appropriate mixtures of EtOAc in hexanes. Individual products are fully characterized as follows:

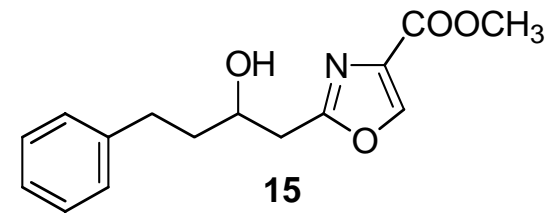

Methyl 2-(2-hydroxy-4-phenylbutyl)oxazole-4-carboxylate (15). ${ }^{1} \mathrm{H} \mathrm{NMR}\left(400 \mathrm{MHz}, \mathrm{CDCl}_{3}\right) \delta 8.15(\mathrm{~s}, 1 \mathrm{H})$, 7.30-7.16 (m, 5H), 4.20-4.13 (m, 1H), $3.89(\mathrm{~s}, 3 \mathrm{H}), 3.01-2.69(\mathrm{~m}, 5 \mathrm{H}), 1.95-1.79(\mathrm{~m}, 2 \mathrm{H}) ;{ }^{13} \mathrm{C}$ NMR $(100$ $\left.\mathrm{MHz}, \mathrm{CDCl}_{3}\right) \delta 163.8,161.7,144.0,141.6,133.2,128.6,126.1,68.3,52.4,38.4,36.0,31.9$; IR (neat) 3401, 2950, 2924, 2853, 1741, 1588, 1435, 1323, 1200, $1111 \mathrm{~cm}^{-1}$; HRMS (EI) calcd for $\mathrm{C}_{15} \mathrm{H}_{17} \mathrm{NO}_{4}\left(\mathrm{M}^{+}\right) 275.1152$, found 275.1157.

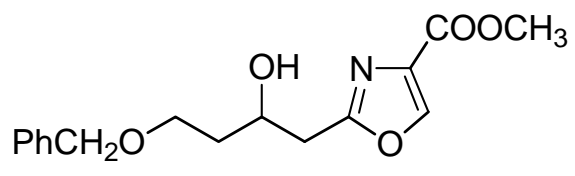

17

Methyl 2-(4-(benzyloxy)-2-hydroxybutyl)oxazole-4-carboxylate (17). ${ }^{1} \mathrm{H} \mathrm{NMR}\left(300 \mathrm{MHz}, \mathrm{CDCl}_{3}\right) \delta 8.15(\mathrm{~s}$, 1H), 7.36-7.26 (m, 5H), $4.50(\mathrm{~s}, 2 \mathrm{H}), 4.39-4.31(\mathrm{~m}, 1 \mathrm{H}), 3.89(\mathrm{~s}, 3 \mathrm{H}), 3.76-3.62(\mathrm{~m}, 2 \mathrm{H}), 3.52(\mathrm{~s}, 1 \mathrm{H}), 2.98(\mathrm{~d}$, $J=6.6 \mathrm{~Hz}, 2 \mathrm{H}), 1.88-1.82(\mathrm{~m}, 2 \mathrm{H}) ;{ }^{13} \mathrm{C} \mathrm{NMR}\left(100 \mathrm{MHz}, \mathrm{CDCl}_{3}\right) \delta 163.7,161.7,144.0,137.9,133.3,128.6$, 
127.9, 127.8, 73.5, 68.7, 68.4, 52.2, 36.0, 36.0; IR (neat) 3426, 2947, 2925, 2851, 1738, 1589, 1456, 1437, 1326, $1114 \mathrm{~cm}^{-1}$; HRMS (EI) calcd for $\mathrm{C}_{16} \mathrm{H}_{19} \mathrm{NO}_{5}\left(\mathrm{M}^{+}\right)$305.1258, found 305.1262.

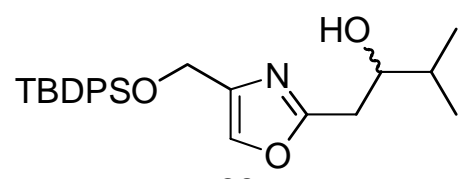

20

1-(4-((tert-Butyldiphenylsilyloxy)methyl)oxazol-2-yl)-3-methylbutan-2-ol (20). ${ }^{1} \mathrm{H}$ NMR (400 MHz, $\left.\mathrm{CDCl}_{3}\right) \delta 7.70(\mathrm{~m}, 4 \mathrm{H}), 7.40(\mathrm{~m}, 7 \mathrm{H}), 4.66(\mathrm{~m}, 2 \mathrm{H}), 3.82(\mathrm{~m}, 1 \mathrm{H}), 3.31(\mathrm{br} \mathrm{s}, 1 \mathrm{H}), 2.90\left(\mathrm{~A}\right.$ of $\mathrm{ABX}, J_{\mathrm{AB}}=16.0$ $\left.\mathrm{Hz}, J_{\mathrm{AX}}=2.7 \mathrm{~Hz}, 1 \mathrm{H}\right), 2.79\left(\mathrm{~B}\right.$ of $\left.\mathrm{ABX}, J_{\mathrm{AB}}=16.0 \mathrm{~Hz}, J_{\mathrm{BX}}=9.5 \mathrm{~Hz}, 1 \mathrm{H}\right), 1.76($ dsept $, J=6.7,6.7 \mathrm{~Hz}, 1 \mathrm{H}), 1.09$ $(\mathrm{s}, 9 \mathrm{H}), 1.01(\mathrm{~d}, J=6.8 \mathrm{~Hz}, 3 \mathrm{H}), 0.97(\mathrm{~d}, J=6.8 \mathrm{~Hz}, 3 \mathrm{H}) ;{ }^{13} \mathrm{C} \mathrm{NMR}\left(100 \mathrm{MHz}, \mathrm{CDCl}_{3}\right) \delta 163.5,140.6,135.5$, 134.8, 133.2, 129.8, 127.7, 73.6, 59.2, 33.1, 32.4, 26.8, 19.2, 18.4, 17.9; IR (neat) 3420, 3071, 3048, 2959 , 2931, 2893, 2858, 1560, 1472, 1428, $1113 \mathrm{~cm}^{-1}$; HRMS (CI/CH4) calcd for $\mathrm{C}_{25} \mathrm{H}_{34} \mathrm{NO}_{3} \mathrm{Si}(\mathrm{M}+\mathrm{H})^{+} 424.2302$, found 424.2293.

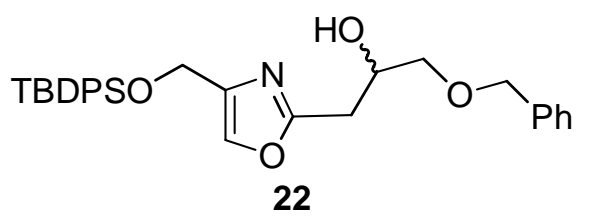

1-(Benzyloxy)-3-(4-((tert-butyldiphenylsilyloxy)methyl)oxazol-2-yl)propan-2-ol (22). ${ }^{1} \mathrm{H}$ NMR (400 MHz, $\left.\mathrm{CDCl}_{3}\right) \delta 7.70(\mathrm{~m}, 4 \mathrm{H}), 7.44-7.31(\mathrm{~m}, 12 \mathrm{H}), 4.65(\mathrm{~m}, 2 \mathrm{H}), 4.57(\mathrm{~s}, 2 \mathrm{H}), 4.28(\mathrm{~m}, 1 \mathrm{H}), 4.11(\mathrm{br} \mathrm{s}, 1 \mathrm{H}), 3.55(\mathrm{~d}, J$ $=5.2 \mathrm{~Hz}, 2 \mathrm{H}), 2.97(\mathrm{~m}, 2 \mathrm{H}), 1.08(\mathrm{~s}, 9 \mathrm{H}) ;{ }^{13} \mathrm{C} \mathrm{NMR}\left(100 \mathrm{MHz}, \mathrm{CDCl}_{3}\right) \delta 162.5,140.9,138.1,135.7,135.1$, 135.0, 133.4, 133.0, 129.0, 128.3, 128.0, 73.6, 73.2, 68.3, 59.4, 32.4, 27.0, 19.4; IR (neat) 3417, 3066, 2956, 2929, 2860, 1727, 1573, 1425, $1108 \mathrm{~cm}^{-1}$; HRMS $\left(\mathrm{CI} / \mathrm{CH}_{4}\right)$ calcd for $\mathrm{C}_{26} \mathrm{H}_{26} \mathrm{NO}_{4} \mathrm{Si}\left(\mathrm{M}-\mathrm{C}_{4} \mathrm{H}_{9}\right)^{+}$444.1626, found 444.1622.

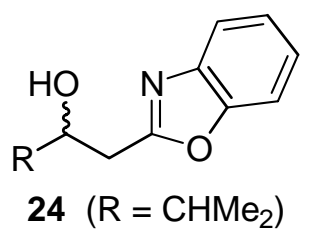


1-(Benzo[d]oxazol-2-yl)-3-methylbutan-2-ol (24). ${ }^{1} \mathrm{H} \mathrm{NMR}\left(400 \mathrm{MHz}, \mathrm{CDCl}_{3}\right) \delta 7.64(\mathrm{~m}, 1 \mathrm{H}), 7.47(\mathrm{~m}, 1 \mathrm{H})$, 7.32-7.27 (m, 2H), $3.99(\mathrm{~m}, 1 \mathrm{H}), 3.52(\mathrm{br} \mathrm{s}, 1 \mathrm{H}), 3.08\left(\mathrm{~A}\right.$ of $\left.\mathrm{ABX}, J_{\mathrm{AB}}=16.0 \mathrm{~Hz}, J_{\mathrm{AX}}=2.7 \mathrm{~Hz}, 1 \mathrm{H}\right), 3.00(\mathrm{~B}$ of $\left.\mathrm{ABX}, J_{\mathrm{AB}}=16.0 \mathrm{~Hz}, J_{\mathrm{BX}}=9.7 \mathrm{~Hz}, 1 \mathrm{H}\right), 1.82(\mathrm{dsept}, J=6.4,6.4 \mathrm{~Hz}, 1 \mathrm{H}), 1.03(\mathrm{~d}, J=6.8 \mathrm{~Hz}, 3 \mathrm{H}), 1.01(\mathrm{~d}, J=$ $6.8 \mathrm{~Hz}, 3 \mathrm{H}) ;{ }^{13} \mathrm{C} \mathrm{NMR}\left(100 \mathrm{MHz}, \mathrm{CDCl}_{3}\right) \delta 165.7,150.5,140.8,124.6,124.2,119.4,110.3,73.6,32.3,33.1$, 18.5, 17.7; IR (neat) 3420, 3043, 2964, 1610, 1562, 1453, 1286, 1242, 1155, 1106, $1001 \mathrm{~cm}^{-1}$; $\mathrm{HRMS}\left(\mathrm{CI} / \mathrm{CH}_{4}\right)$ calcd for $\mathrm{C}_{12} \mathrm{H}_{16} \mathrm{NO}_{2}(\mathrm{M}+\mathrm{H})^{+} 206.1176$, found 206.1168 .

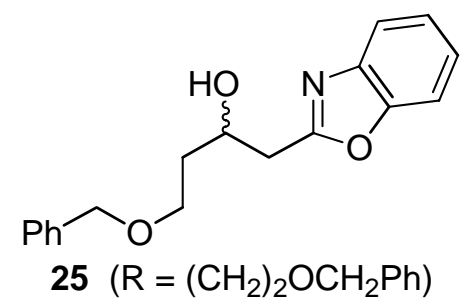

1-(Benzo[d]oxazol-2-yl)-3-(benzyloxy)propan-2-ol (25). ${ }^{1} \mathrm{H}$ NMR $\left(400 \mathrm{MHz}, \mathrm{CDCl}_{3}\right) \delta 7.66(\mathrm{~m}, 1 \mathrm{H}), 7.48$ $(\mathrm{m}, 1 \mathrm{H}), 7.33-7.28(\mathrm{~m}, 7 \mathrm{H}), 4.58,(\mathrm{~s}, 2 \mathrm{H}), 4.45(\mathrm{~m}, 1 \mathrm{H}), 3.66-3.58(\mathrm{~m}, 2 \mathrm{H}), 3.33(\mathrm{~m}, 2 \mathrm{H}) ;{ }^{13} \mathrm{C} \mathrm{NMR}(100 \mathrm{MHz}$, $\left.\mathrm{CDCl}_{3}\right) \delta 164.5,150.5,141.0,137.7,128.4,127.7,127.7,124.7,124.2,119.5,110.4,73.4,73.0,68.0,33.0 ; \mathrm{IR}$ (neat) $3368,3062,3029,2914,2857,1607,1568,1450,1241,1105 \mathrm{~cm}^{-1}$; HRMS (CI/CH 4$)$ calcd for $\mathrm{C}_{7} \mathrm{H}_{18} \mathrm{NO}_{3}$ $(\mathrm{M}+\mathrm{H})^{+} 284.1281$, found 284.1270 .

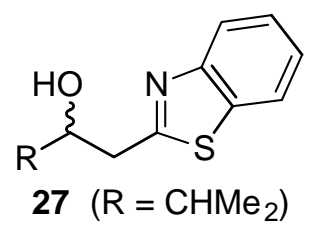

1-(Benzo[d]thiazol-2-yl)-3-methylbutan-2-ol (27). ${ }^{1} \mathrm{H} \mathrm{NMR}\left(400 \mathrm{MHz}, \mathrm{CDCl}_{3}\right) \delta 7.95(\mathrm{~d}, \mathrm{~J}=8.1 \mathrm{~Hz}, 1 \mathrm{H})$, $7.83(\mathrm{~d}, J=8.0 \mathrm{~Hz}, 1 \mathrm{H}), 7.48-7.38(\mathrm{~m}, 2 \mathrm{H}), 3.93(\mathrm{~m}, 1 \mathrm{H}), 3.25\left(\mathrm{~A}\right.$ of $\left.\mathrm{ABX}, J_{\mathrm{AB}}=15.6 \mathrm{~Hz}, J_{\mathrm{AX}}=2.4 \mathrm{~Hz}, 1 \mathrm{H}\right)$, $3.14\left(\mathrm{~B}\right.$ of $\left.\mathrm{ABX}, J_{\mathrm{AB}}=15.6, J_{\mathrm{BX}}=9.5 \mathrm{~Hz}, 1 \mathrm{H}\right), 1.82(\mathrm{dsept}, J=6.7,6.7 \mathrm{~Hz}, 1 \mathrm{H}), 1.04(\mathrm{~d}, J=7.0 \mathrm{~Hz}, 3 \mathrm{H}), 1.01$ $(\mathrm{d}, J=7.0 \mathrm{~Hz}, 1 \mathrm{H}) ;{ }^{13} \mathrm{C} \mathrm{NMR}\left(100 \mathrm{MHz}, \mathrm{CDCl}_{3}\right) \delta 170.1,152.9,134.8,126.2,125.0,122.7,121.6,75.4,38.1$, 33.5, 18.7, 18.0; IR (neat) 3420, 3060, 3026, 2963, 1502, 1434, 1313, 1148, $1077 \mathrm{~cm}^{-1}$; HRMS (CI/CH 4$)$ calcd for $\mathrm{C}_{12} \mathrm{H}_{16} \mathrm{NOS}(\mathrm{M}+\mathrm{H})^{+} 222.0947$, found 222.0948 . 


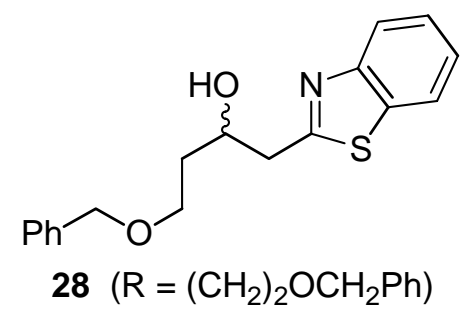

1-(Benzo[d]thiazol-2-yl)-3-(benzyloxy)propan-2-ol (28). ${ }^{1} \mathrm{H} \mathrm{NMR}\left(400 \mathrm{MHz}, \mathrm{CDCl}_{3}\right) \delta 7.97(\mathrm{~d}, J=8.0 \mathrm{~Hz}$, 1H), $7.84 \mathrm{~d},(J=8.0 \mathrm{~Hz}, 1 \mathrm{H}), 7.48-7.28(\mathrm{~m}, 7 \mathrm{H}), 4.58,(\mathrm{~s}, 2 \mathrm{H}), 4.39(\mathrm{~m}, 1 \mathrm{H}), 3.60$ (br s, $1 \mathrm{H}), 3.60(\mathrm{~d}, J=5.4$ $\mathrm{Hz}, 2 \mathrm{H}), 3.40-3.24(\mathrm{~m}, 2 \mathrm{H}) ;{ }^{13} \mathrm{C} \mathrm{NMR}\left(100 \mathrm{MHz}, \mathrm{CDCl}_{3}\right) \delta 169.0,153.3,138.3,135.4,128.9,128.2,128.2$, 16.5, 125.4, 123.0, 121.9, 73.9, 73.6, 69.9, 38.2; IR (neat) 3420, 3060, 2963, 1502, 1455, 1434, 1313, 1148 , $1077 \mathrm{~cm}^{-1}$; HRMS $\left(\mathrm{CI} / \mathrm{CH}_{4}\right)$ calcd for $\mathrm{C}_{17} \mathrm{H}_{18} \mathrm{NO}_{2} \mathrm{~S}(\mathrm{M}+\mathrm{H})^{+}$300.1053, found 300.1044 .

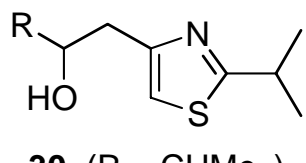

$30\left(\mathrm{R}=\mathrm{CHMe}_{2}\right)$

1-(2-Isopropylthiazol-4-yl)-3-methylbutan-2-ol (30). ${ }^{1} \mathrm{H} \mathrm{NMR}\left(400 \mathrm{MHz}, \mathrm{CDCl}_{3}\right) \delta 6.79$ (s, $\left.1 \mathrm{H}\right), 4.49$ (s, 1H), $3.61(\mathrm{~m}, 1 \mathrm{H}), 3.24$ (sept, $J=7.0 \mathrm{~Hz}, 1 \mathrm{H}), 2.87(\mathrm{dd}, J=2.3,14.7 \mathrm{~Hz}, 1 \mathrm{H}), 2.71(\mathrm{dd}, J=9.4,14.7 \mathrm{~Hz}, 1 \mathrm{H})$, 1.68 (dsept, $J=6.4,6.4 \mathrm{~Hz}, 1 \mathrm{H}), 1.35(\mathrm{~d}, J=7.0 \mathrm{~Hz}, 6 \mathrm{H}), 0.98(\mathrm{~d}, J=6.7 \mathrm{~Hz}, 3 \mathrm{H}), 0.94(\mathrm{~d}, J=6.7 \mathrm{~Hz}, 3 \mathrm{H}) ;{ }^{13} \mathrm{C}$ NMR $\left(100 \mathrm{MHz}, \mathrm{CDCl}_{3}\right) \delta 178.1,154.2,112.6,76.0,35.1,33.5,33.2,23.1,18.8,18.1$; IR (neat) 3375, 3102, 2965, 2928, 2869, 1512, 1459, $1165 \mathrm{~cm}^{-1}$; HRMS $\left(\mathrm{CI} / \mathrm{CH}_{4}\right)$ calcd for $\mathrm{C}_{11} \mathrm{H}_{20} \mathrm{NOS}(\mathrm{M}+\mathrm{H})^{+} 214.1260$, found 214.1268.

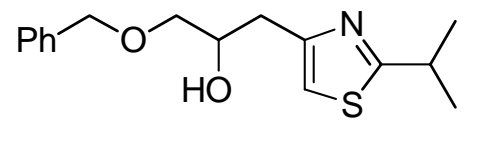

$31\left(\mathrm{R}=\left(\mathrm{CH}_{2}\right)_{2} \mathrm{OCH}_{2} \mathrm{Ph}\right)$

1-(Benzyloxy)-3-(2-isopropylthiazol-4-yl)propan-2-ol (31). ${ }^{1} \mathrm{H}$ NMR $\left(400 \mathrm{MHz}, \mathrm{CDCl}_{3}\right) \delta$ 7.36-7.26 (m, $5 \mathrm{H}), 6.82(\mathrm{~s}, 1 \mathrm{H}), 4.57(\mathrm{~s}, 2 \mathrm{H}), 4.22-4.08(\mathrm{~m}, 2 \mathrm{H}), 3.52\left(\mathrm{~A}\right.$ of $\left.\mathrm{ABX}, J_{\mathrm{AB}}=9.5 \mathrm{~Hz}, J_{\mathrm{AX}}=6.0 \mathrm{~Hz}, 1 \mathrm{H}\right), 3.47(\mathrm{~B}$ of $\left.\mathrm{ABX}, J_{\mathrm{AB}}=9.5, J_{\mathrm{BX}}=5.2 \mathrm{~Hz}, 1 \mathrm{H}\right), 3.27(\mathrm{sept}, J=6.9 \mathrm{~Hz}, 1 \mathrm{H}), 2.98(\mathrm{dd}, J=3.6,14.8 \mathrm{~Hz}, 1 \mathrm{H}), 2.88(\mathrm{dd} J=$ 8.1, $14.8 \mathrm{~Hz}, 1 \mathrm{H}), 1.37$ (d, $J=7.0 \mathrm{~Hz}, 6 \mathrm{H}) ;{ }^{13} \mathrm{C} \mathrm{NMR}\left(100 \mathrm{MHz}, \mathrm{CDCl}_{3}\right) \delta 178.3,153.1,138.5,128.5,128.1$, 127.8, 113.2, 73.8, 73.6, 70.3, 35.1, 33.3, 23.3; IR (neat) 3392, 3029, 2963, 2926, 2866, 1525, 1455, $1102 \mathrm{~cm}^{-1}$; HRMS $\left(\mathrm{CI} / \mathrm{CH}_{4}\right)$ calcd for $\mathrm{C}_{16} \mathrm{H}_{22} \mathrm{NO}_{2} \mathrm{~S}(\mathrm{M}+\mathrm{H})^{+} 292.1366$, found 292.1365. 


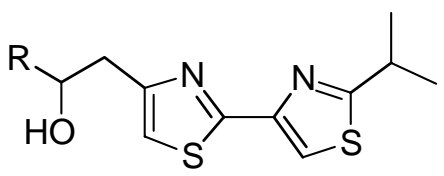

$33\left(\mathrm{R}=\mathrm{CHMe}_{2}\right)$

1-(2'-Isopropyl-2,4'-bithiazol-4-yl)-3-methylbutan-2-ol (33). ${ }^{1} \mathrm{H} \mathrm{NMR}\left(400 \mathrm{MHz}, \mathrm{CDCl}_{3}\right) \delta 7.77(\mathrm{~s}, 1 \mathrm{H})$, $6.97(\mathrm{~s}, 1 \mathrm{H}), 4.12(\mathrm{br} \mathrm{s}, 1 \mathrm{H}), 3.70(\mathrm{~m}, 1 \mathrm{H}), 3.36(\mathrm{sept}, J=6.8 \mathrm{~Hz}, 1 \mathrm{H}), 2.97\left(\mathrm{~A}\right.$ of $\mathrm{ABX}, J_{\mathrm{AB}}=14.8 \mathrm{~Hz}, J_{\mathrm{AX}}=$ $2.2 \mathrm{~Hz}, 1 \mathrm{H}), 2.83\left(\mathrm{~B}\right.$ of $\left.\mathrm{ABX}, J_{\mathrm{AB}}=14.8 \mathrm{~Hz}, J_{\mathrm{BX}}=9.4 \mathrm{~Hz}, 1 \mathrm{H}\right), 1.73(\mathrm{dsept}, J=6.6,6.6 \mathrm{~Hz}, 1 \mathrm{H}), 1.42(\mathrm{~d}, J=$ $7.0 \mathrm{~Hz}, 6 \mathrm{H}), 1.01(\mathrm{~d}, J=6.8 \mathrm{~Hz}, 3 \mathrm{H}), 0.98(\mathrm{~d}, J=6.8 \mathrm{~Hz}, 3 \mathrm{H}) ;{ }^{13} \mathrm{C}$ NMR $\left(100 \mathrm{MHz}, \mathrm{CDCl}_{3}\right) \delta 178.9,163.1$, $155.8,148.6,115.0,114.8,76.1,35.3,33.5,29.8,23.2,18.8,18.1$; IR (neat) 3258, 3101, 2959, 2924, 2875 , $1518,1312,1183,1123,1001 \mathrm{~cm}^{-1}$; HRMS $\left(\mathrm{CI} / \mathrm{CH}_{4}\right)$ calcd for $\mathrm{C}_{16} \mathrm{H}_{25} \mathrm{~N}_{2} \mathrm{OS}_{2}\left(\mathrm{M}+\mathrm{CH}_{3}\right)^{+} 325.1403$, found 325.1400 .

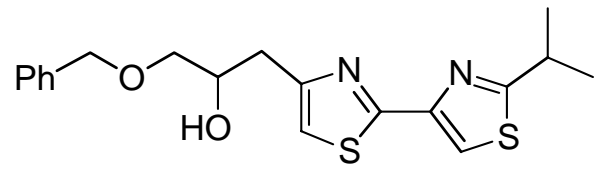

$34\left(\mathrm{R}=\left(\mathrm{CH}_{2}\right)_{2} \mathrm{OCH} \mathrm{H}_{2} \mathrm{Ph}\right)$

1-(Benzyloxy)-3-(2'-isopropyl-2,4'-bithiazol-4-yl)propan-2-ol (34). ${ }^{1} \mathrm{H}$ NMR (400 MHz, $\left.\mathrm{CDCl}_{3}\right) \delta 7.76$ (s, 1H), 7.35-7.28 (m, 5H), $6.99(\mathrm{~s}, 1 \mathrm{H}), 4.57(\mathrm{~s}, 2 \mathrm{H}), 4.22(\mathrm{~m}, 1 \mathrm{H}), 3.85$ (br s, 1H), $3.52(\mathrm{~m}, 2 \mathrm{H}), 3.37$ (sept, $J=$ $6.8 \mathrm{~Hz}, 1 \mathrm{H}), 3.04\left(\mathrm{~A}\right.$ of $\left.\mathrm{ABX}, J_{\mathrm{AB}}=15.0 \mathrm{~Hz}, J_{\mathrm{AX}}=4.2 \mathrm{~Hz}, 1 \mathrm{H}\right), 2.97\left(\mathrm{~B}\right.$ of $\mathrm{ABX}, J_{\mathrm{AB}}=15.0 \mathrm{~Hz}, J_{\mathrm{BX}}=7.6 \mathrm{~Hz}$, 1H), $1.43(\mathrm{~d}, J=6.8 \mathrm{~Hz}, 6 \mathrm{H}) ;{ }^{13} \mathrm{C} \mathrm{NMR}\left(100 \mathrm{MHz}, \mathrm{CDCl}_{3}\right) \delta 178.9,163.1,154.6,148.7,138.3,128.6,127.9$, 127.8, 115.4, 114.8, 77.5, 73.6, 70.1, 35.1, 33.5, 23.3; IR (neat) 3403, 2966, 2924, 2867, 1457, $1102 \mathrm{~cm}^{-1}$; HRMS $\left(\mathrm{CI} / \mathrm{CH}_{4}\right)$ calcd for $\mathrm{C}_{19} \mathrm{H}_{23} \mathrm{O}_{2} \mathrm{~N}_{2} \mathrm{~S}_{2}(\mathrm{M}+\mathrm{H})^{+} 375.1195$, found 375.1179 .

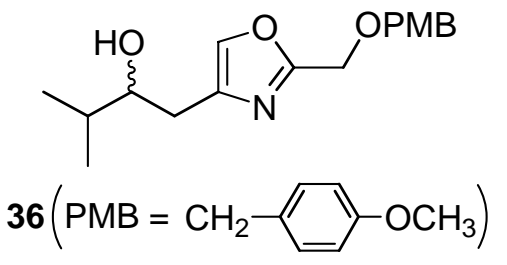

1-(2-((4-Methoxybenzyloxy)methyl)oxazol-4-yl)-3-methylbutan-2-ol (36). ${ }^{1} \mathrm{H} \mathrm{NMR}\left(400 \mathrm{MHz}, \mathrm{CDCl}_{3}\right) \delta$ $7.46(\mathrm{~s}, 1 \mathrm{H}), 7.28(\mathrm{~d}, J=8.6 \mathrm{~Hz}, 2 \mathrm{H}), 6.88(\mathrm{~d}, J=8.6 \mathrm{~Hz}, 2 \mathrm{H}), 4.55(\mathrm{~s}, 2 \mathrm{H}), 4.54(\mathrm{~s}, 2 \mathrm{H}), 3.81(\mathrm{~s}, 3 \mathrm{H}), 3.64(\mathrm{~m}$, 
$1 \mathrm{H}), 2.94(\mathrm{~d}, J=3.2 \mathrm{~Hz}, 1 \mathrm{H}), 2.72\left(\mathrm{~A}\right.$ of $\left.\mathrm{ABX}, J_{\mathrm{AB}}=15.0 \mathrm{~Hz}, J_{\mathrm{AX}}=2.5 \mathrm{~Hz}, 1 \mathrm{H}\right), 2.56\left(\mathrm{~B}\right.$ of $\mathrm{ABX}, J_{\mathrm{AB}}=15.0$ $\left.\mathrm{Hz}, J_{\mathrm{BX}}=9.5 \mathrm{~Hz}, 1 \mathrm{H}\right), 1.73(\mathrm{dqq}, J=6.8,6.8,6.8 \mathrm{~Hz}, 1 \mathrm{H}), 0.99(\mathrm{~d}, J=6.8 \mathrm{~Hz}, 3 \mathrm{H}), 0.97(\mathrm{~d}, J=6.8 \mathrm{~Hz}, 3 \mathrm{H})$; ${ }^{13} \mathrm{C}$ NMR $\left(100 \mathrm{MHz}, \mathrm{CDCl}_{3}\right) \delta 161.0,159.7,138.8,136.0,129.9,129.3,114.1,75.7,72.8,63.6,55.4,33.5$, 30.3, 18.8, 17.9; IR (neat) 3391, 2953, 2913, 2849, 1609, 1514, 1460, 1245, 1086, $1029 \mathrm{~cm}^{-1}$; $\mathrm{HRMS}\left(\mathrm{CI} / \mathrm{CH}_{4}\right)$ calcd for $\mathrm{C}_{17} \mathrm{H}_{24} \mathrm{O}_{4} \mathrm{~N}_{1}(\mathrm{M}+\mathrm{H})^{+} 306.1700$, found 306.1705 . 


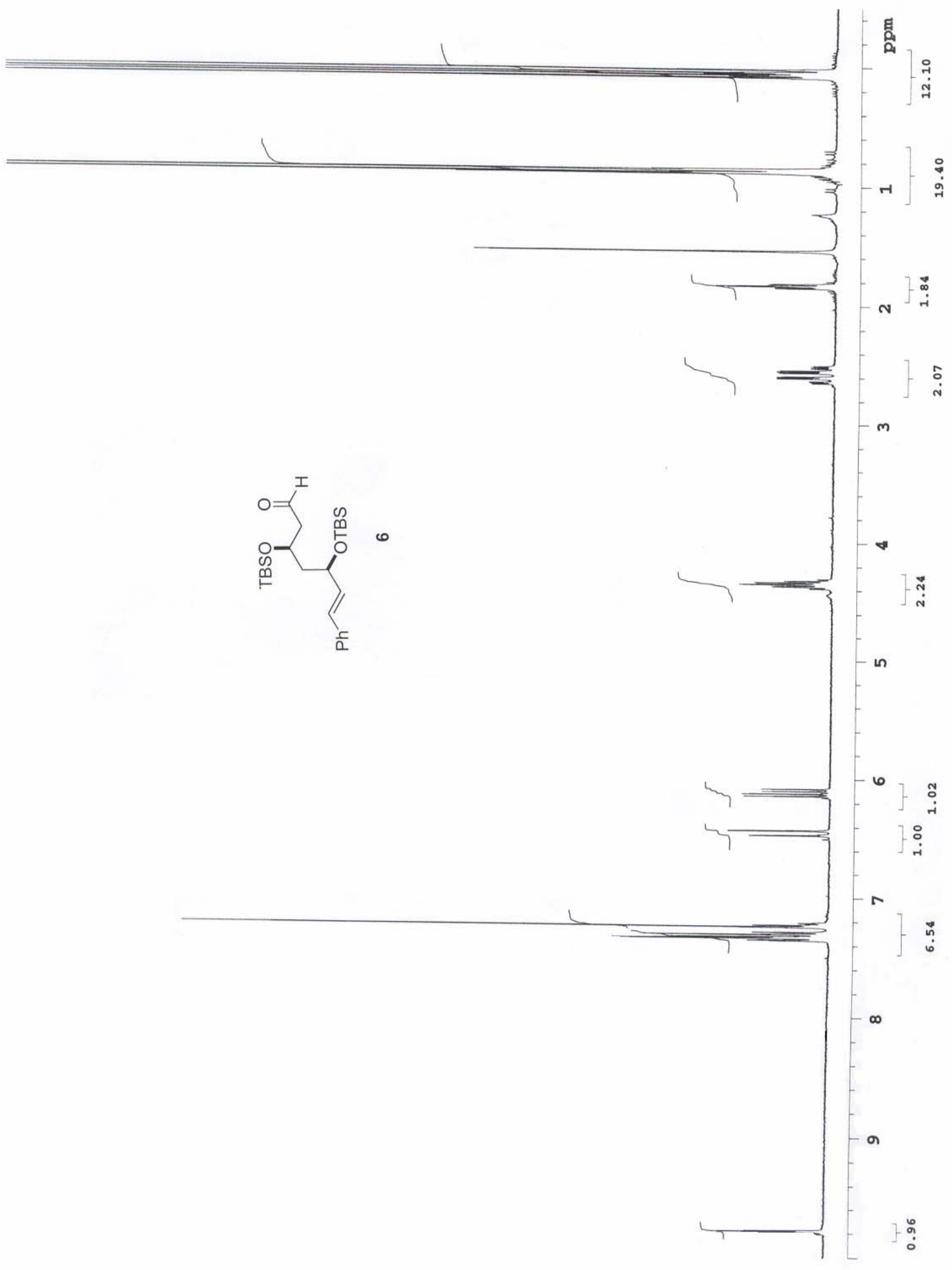




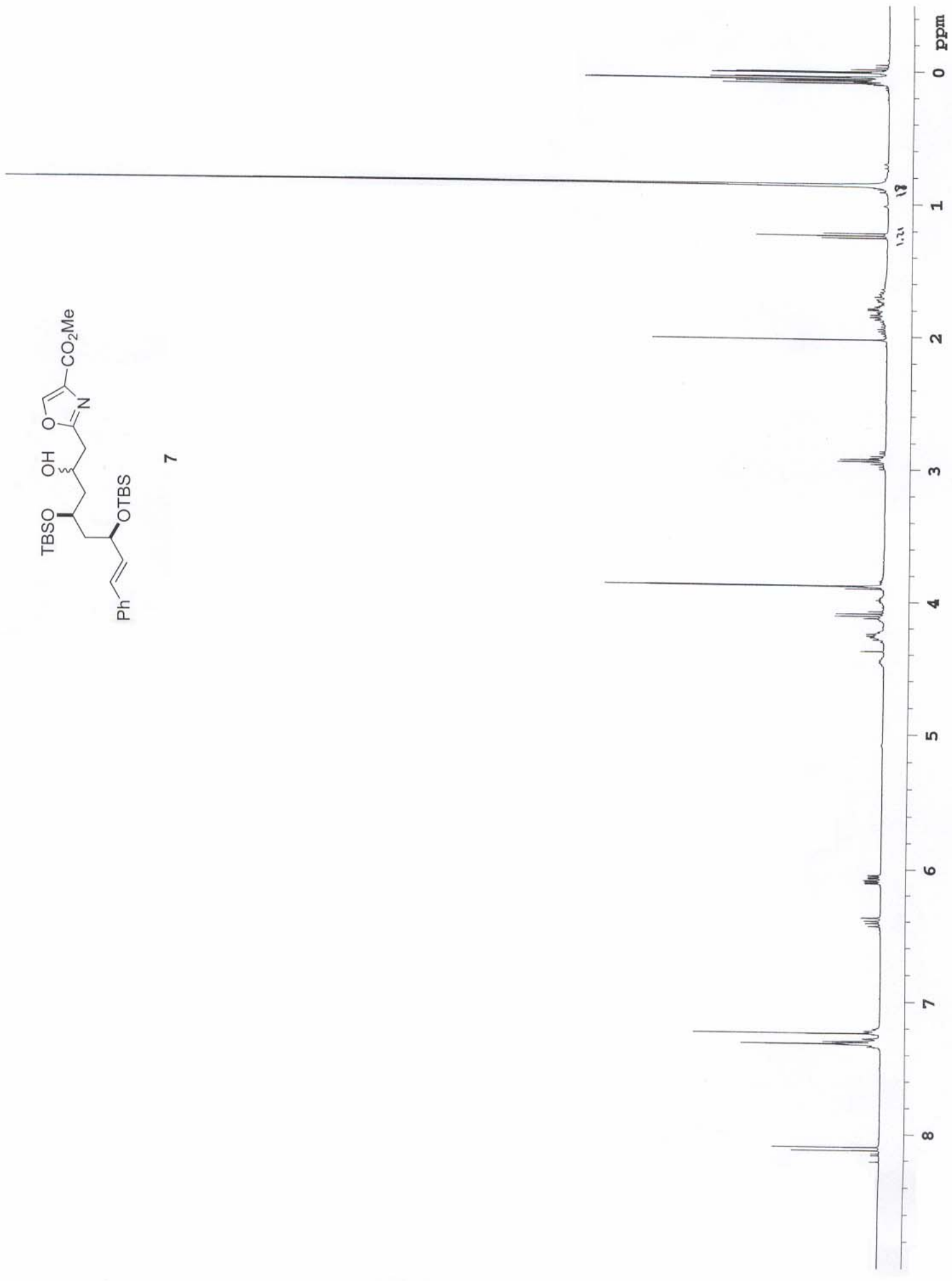

S-18 


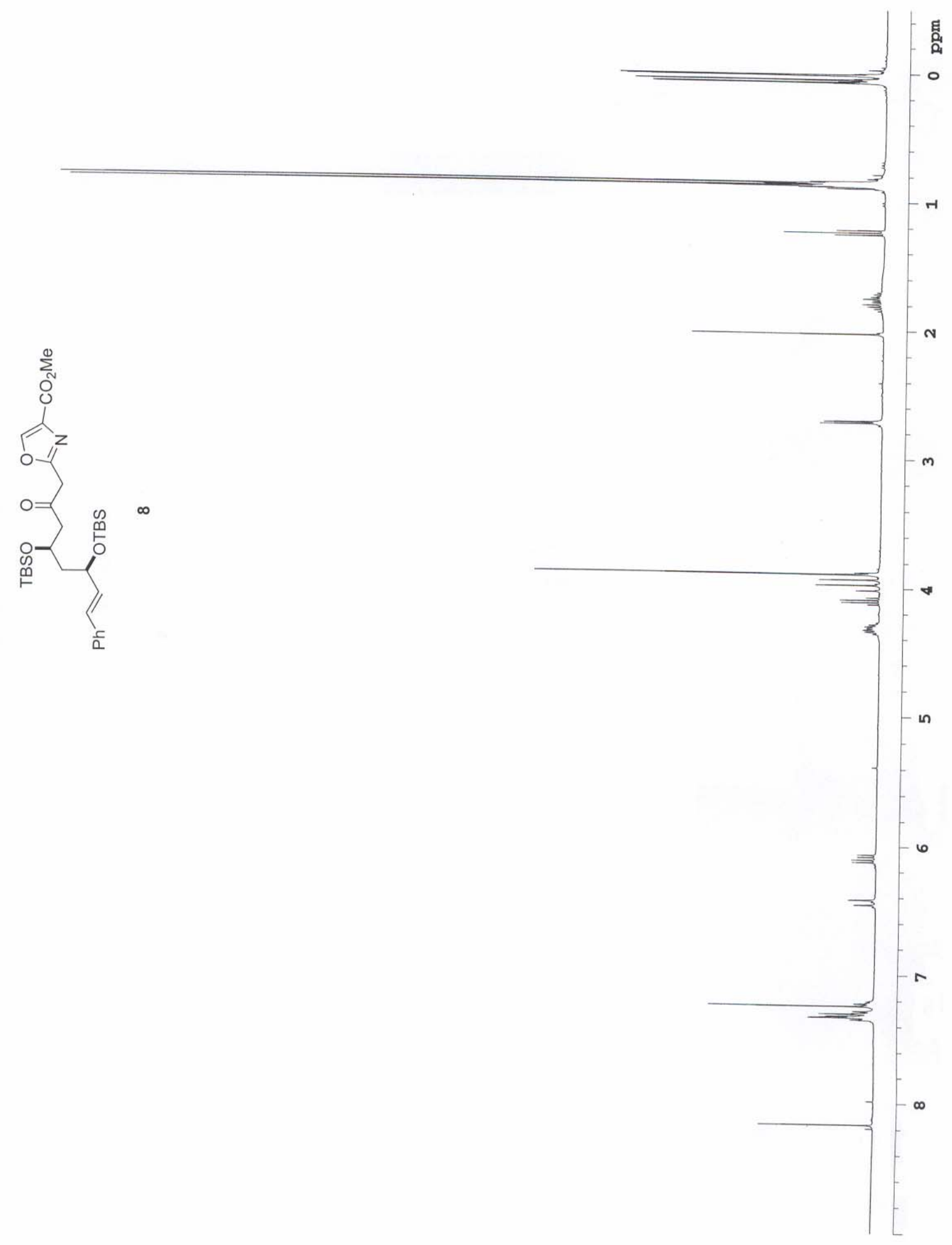

S-19 

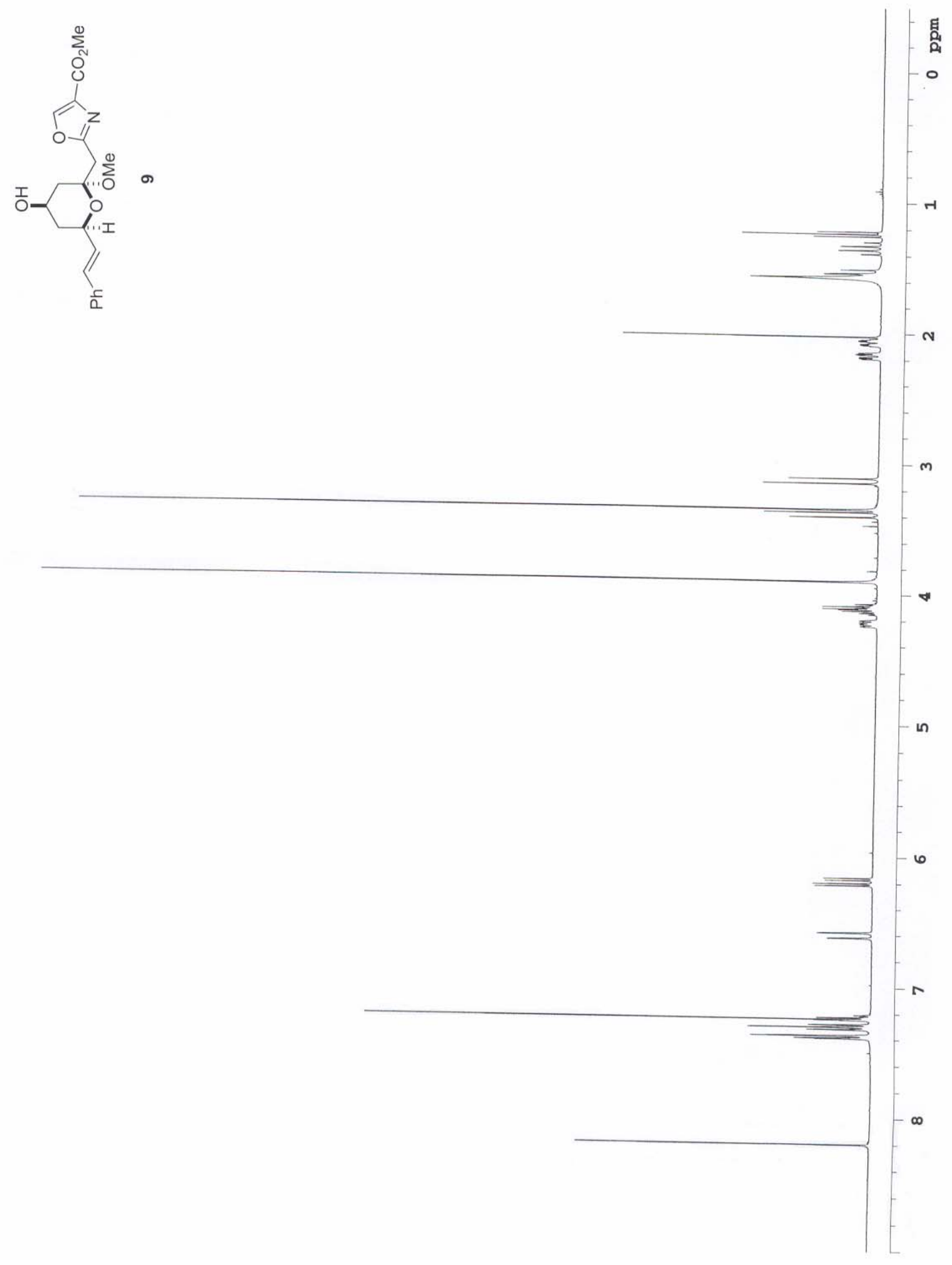


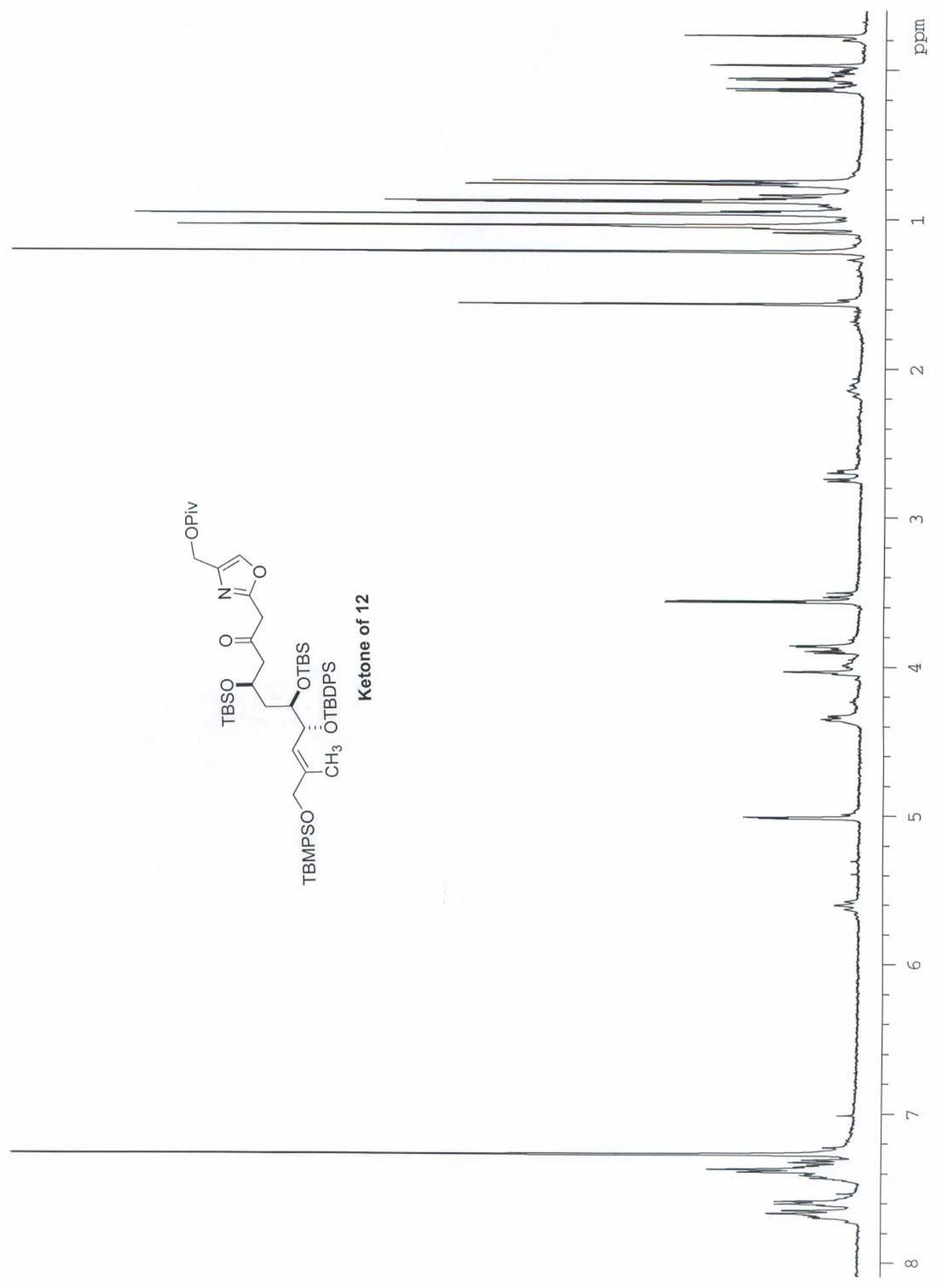




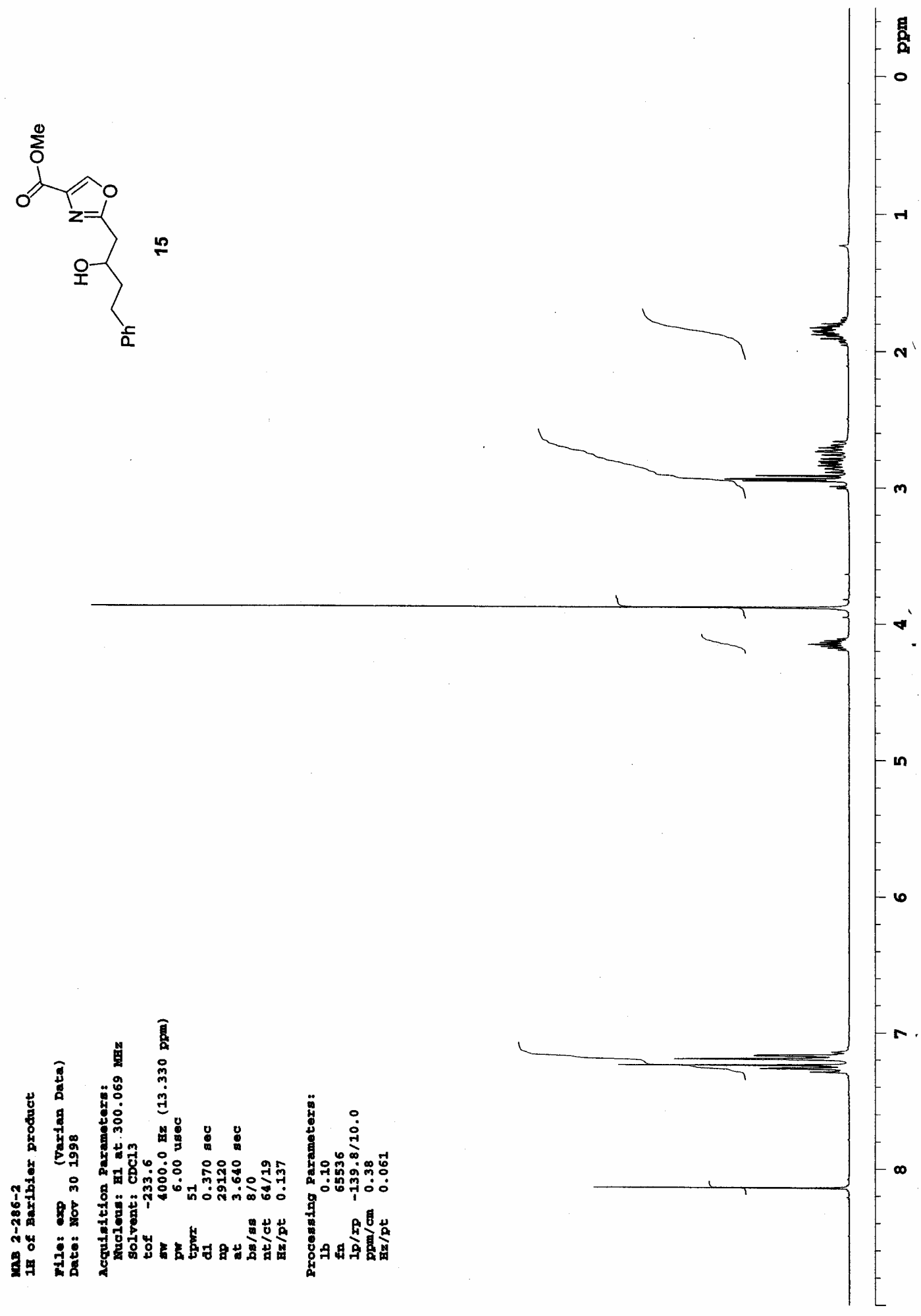



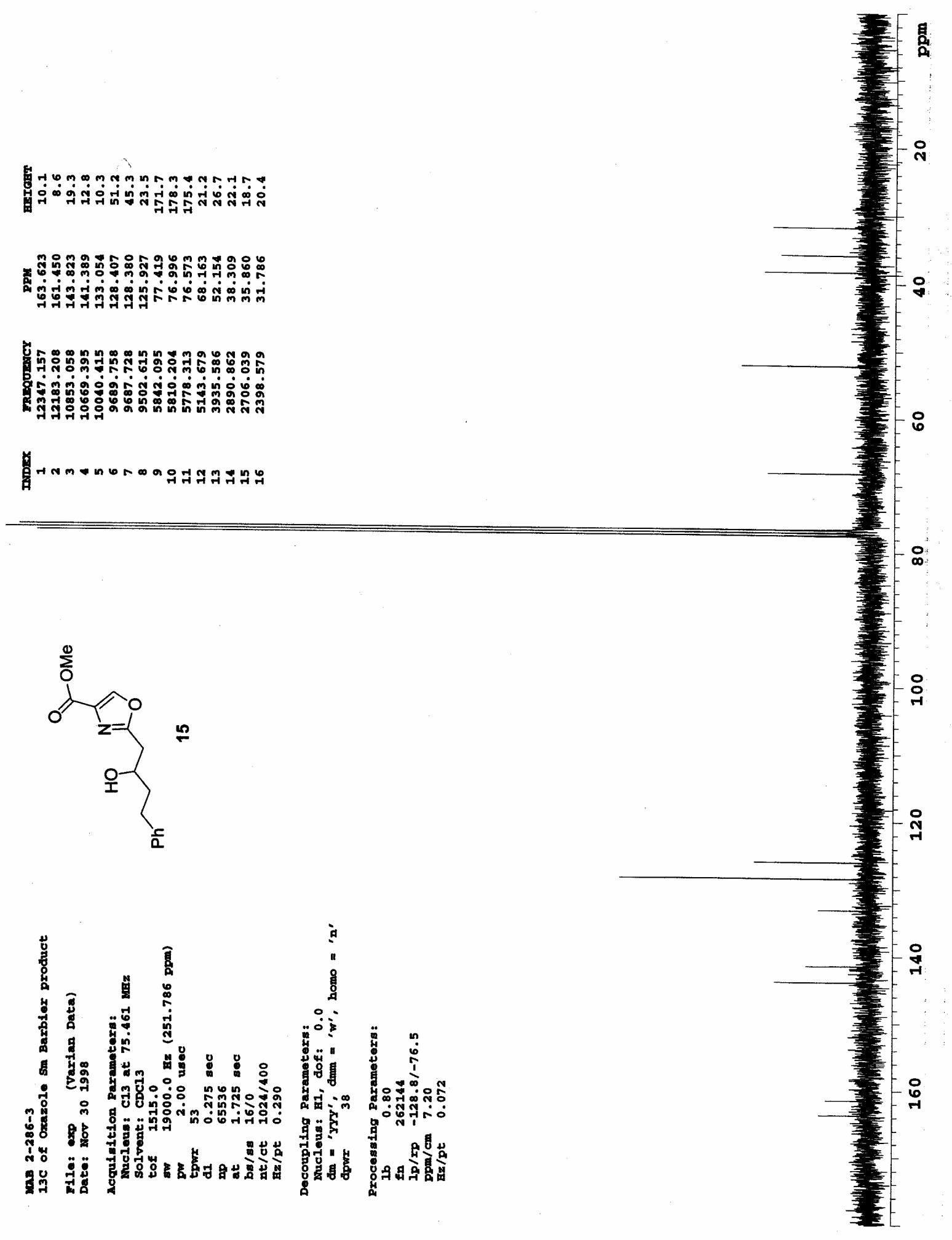


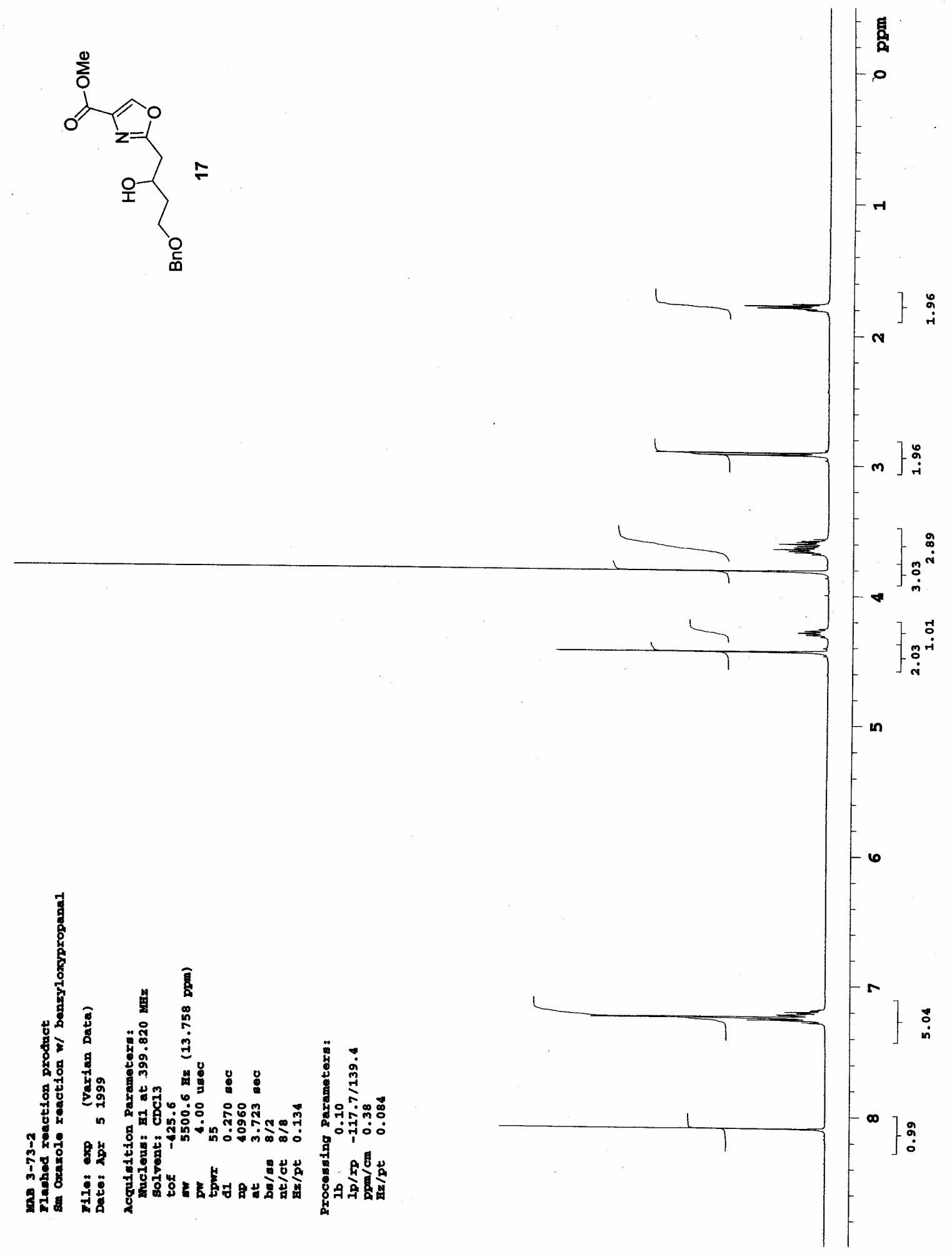



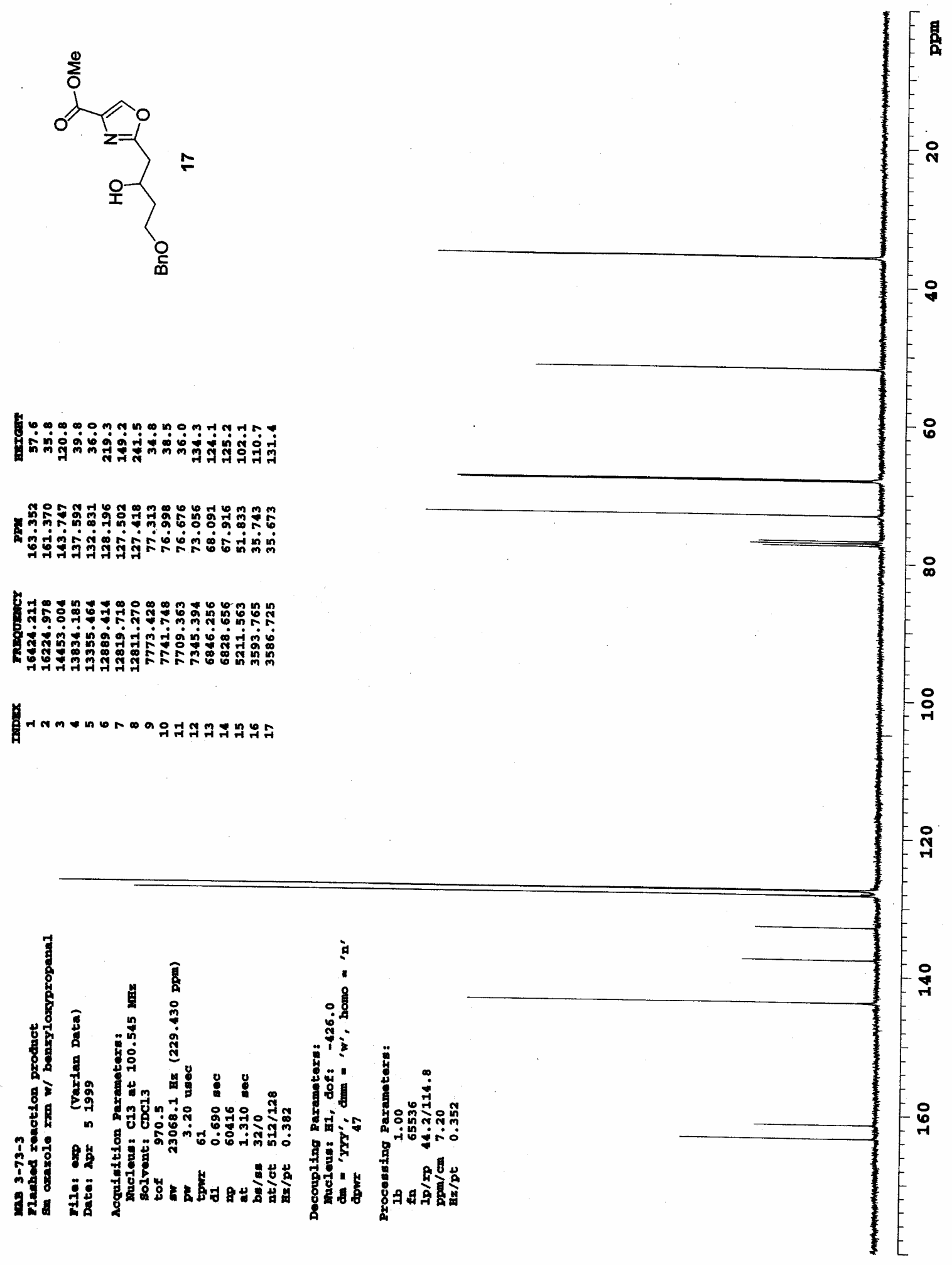


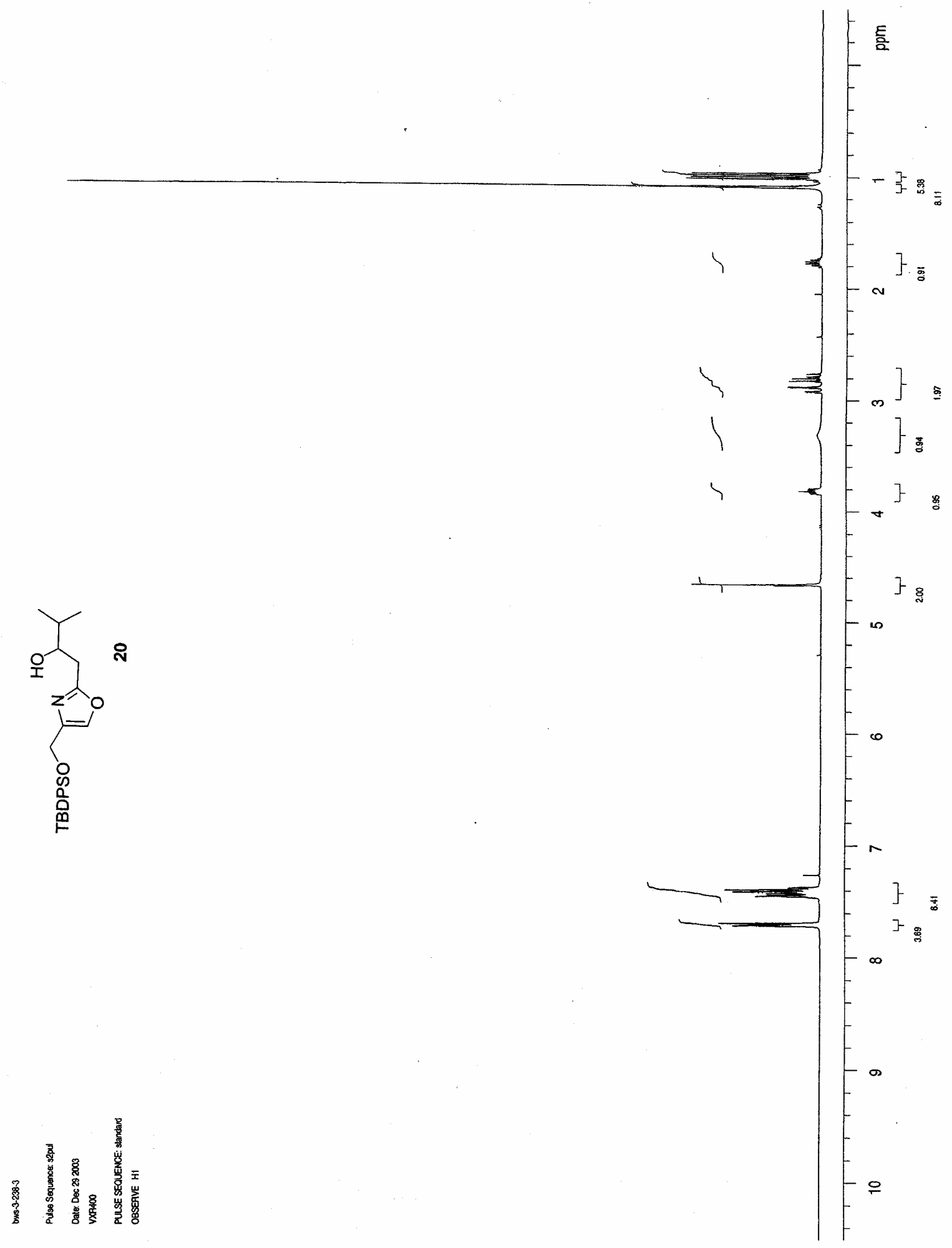




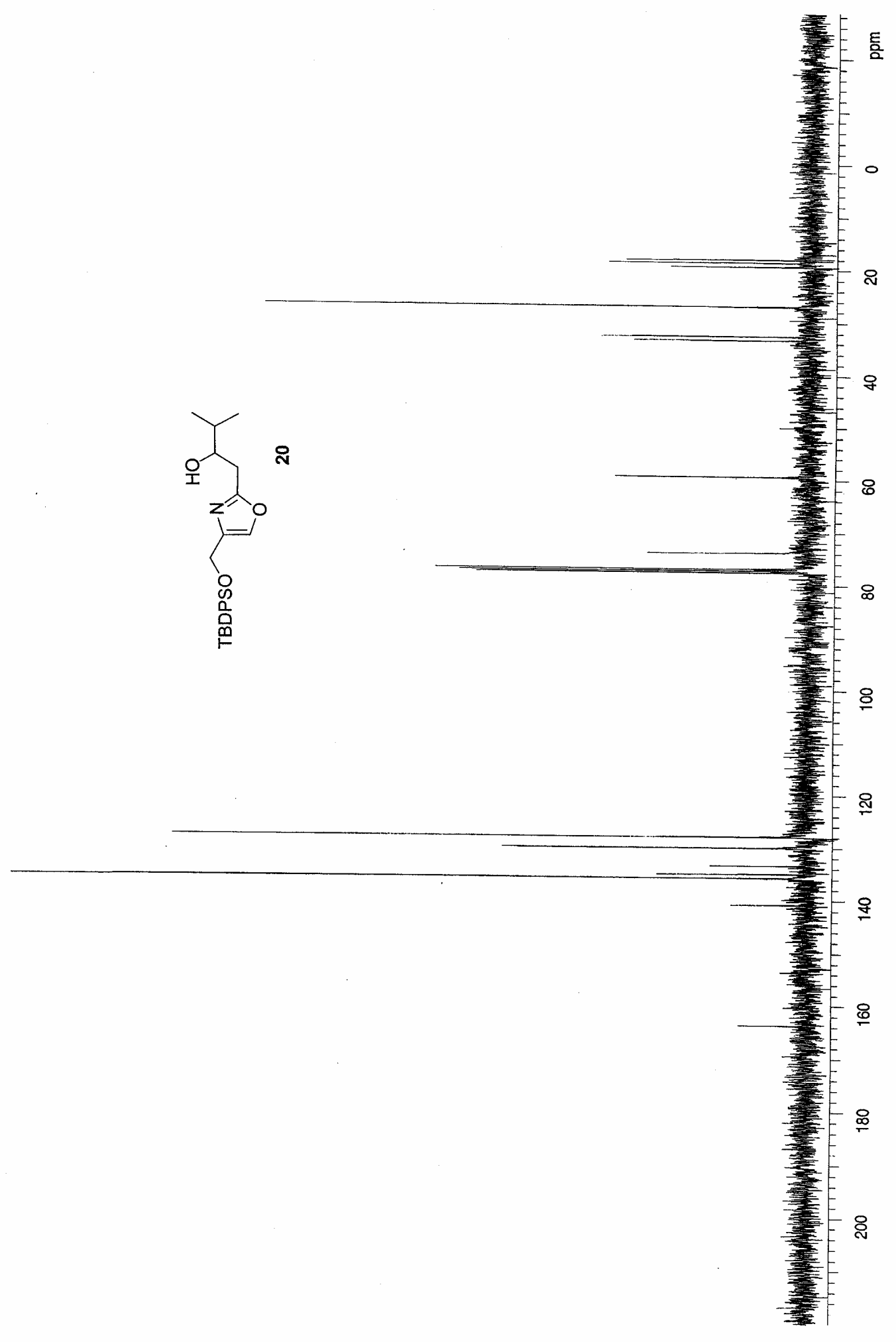




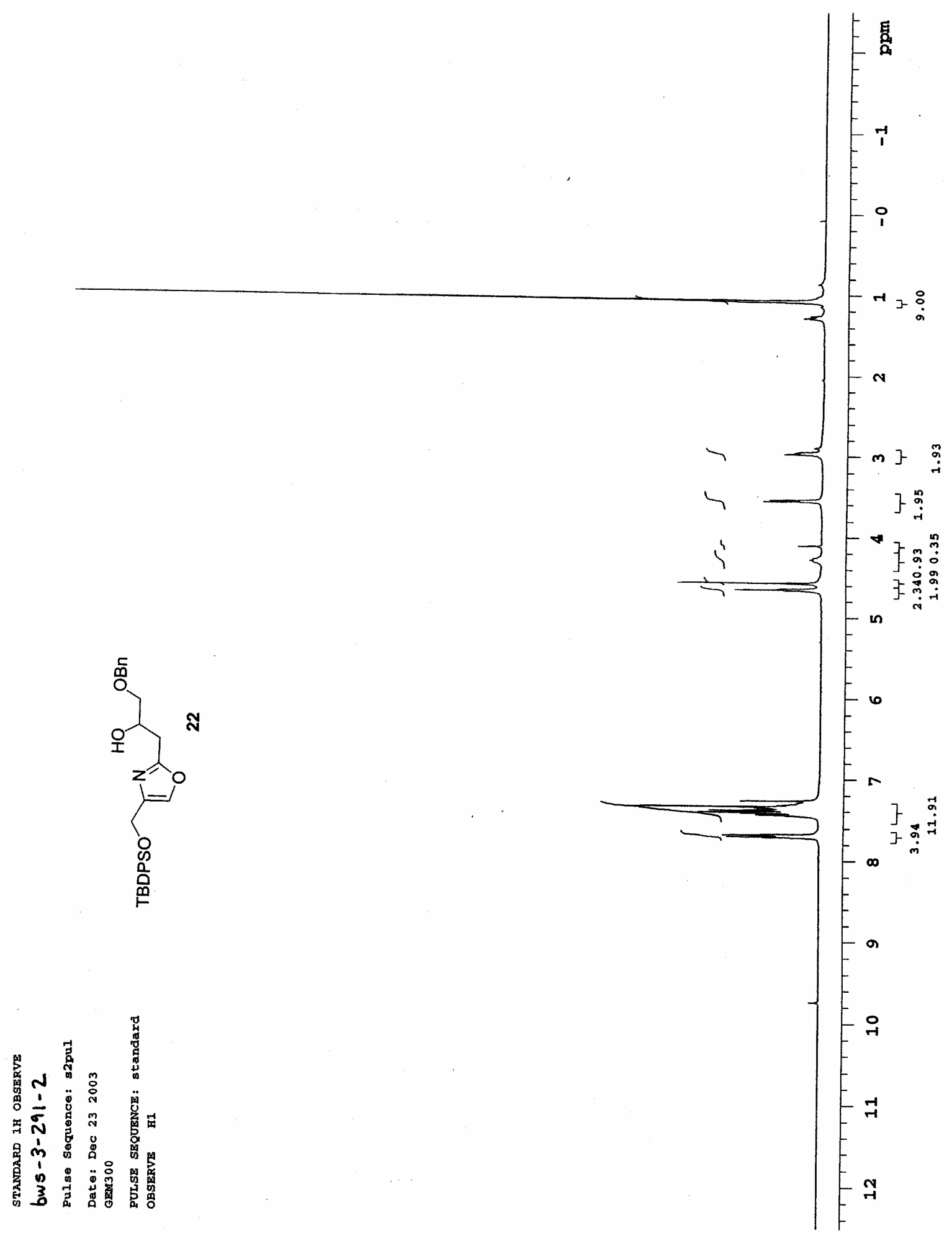



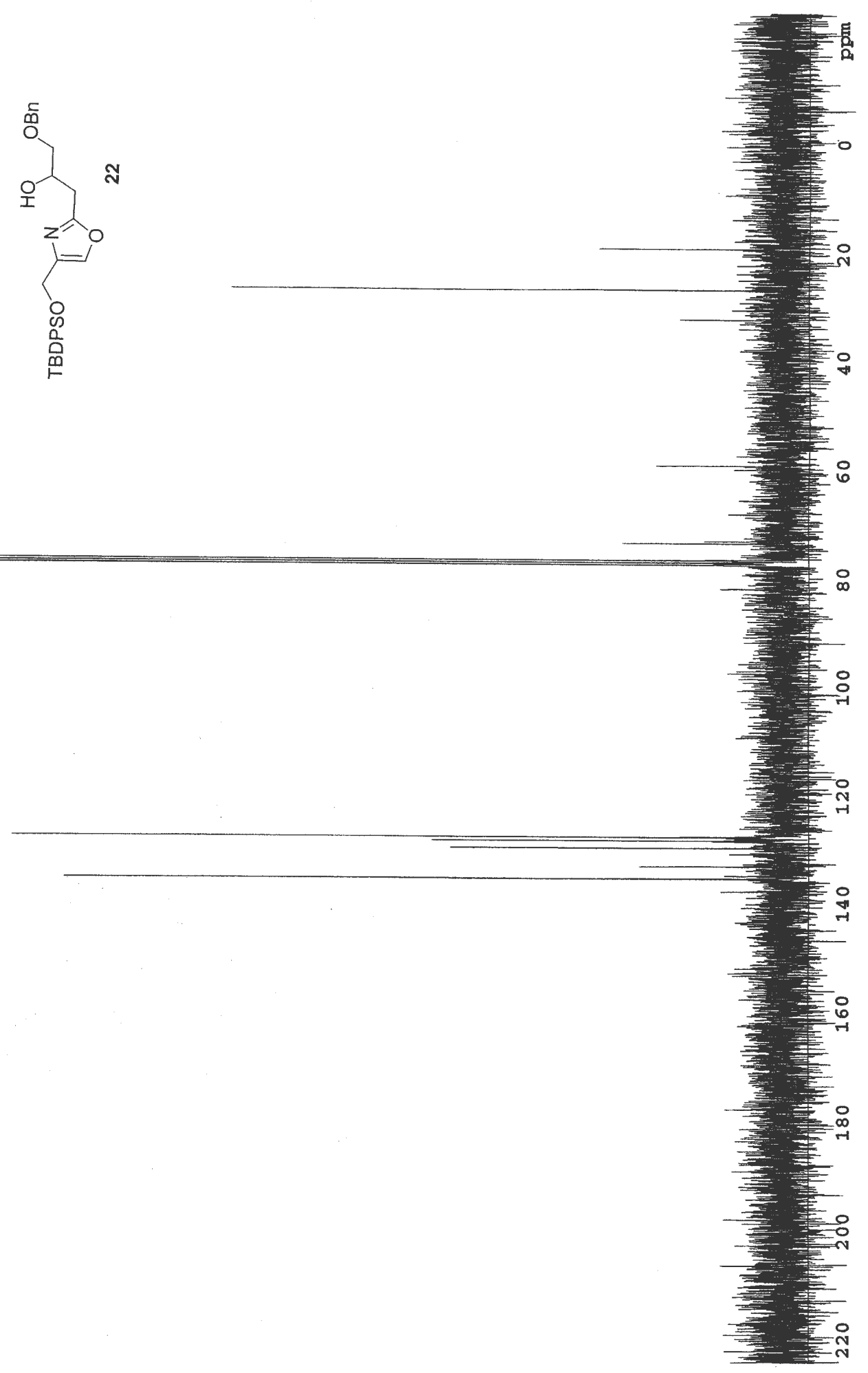


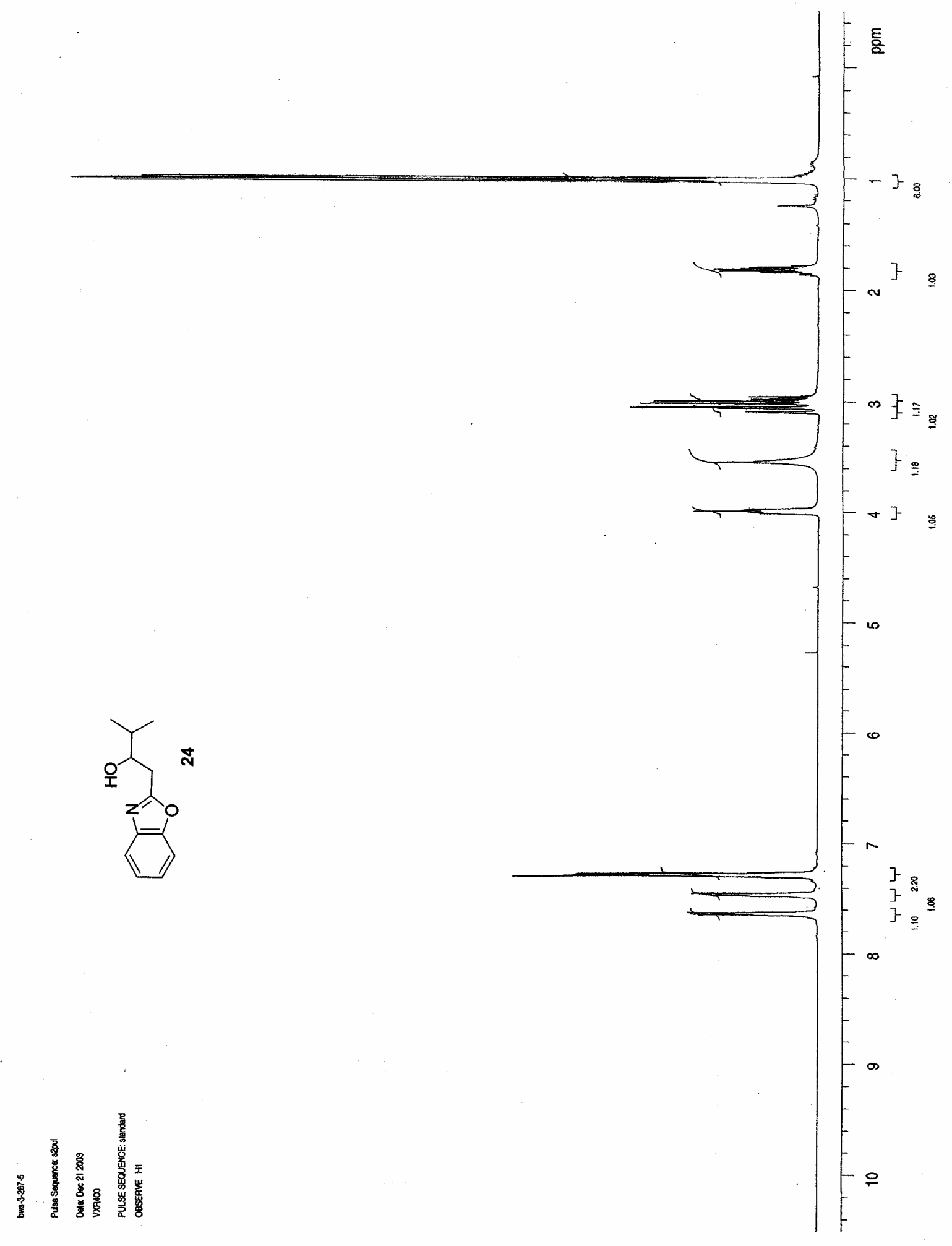




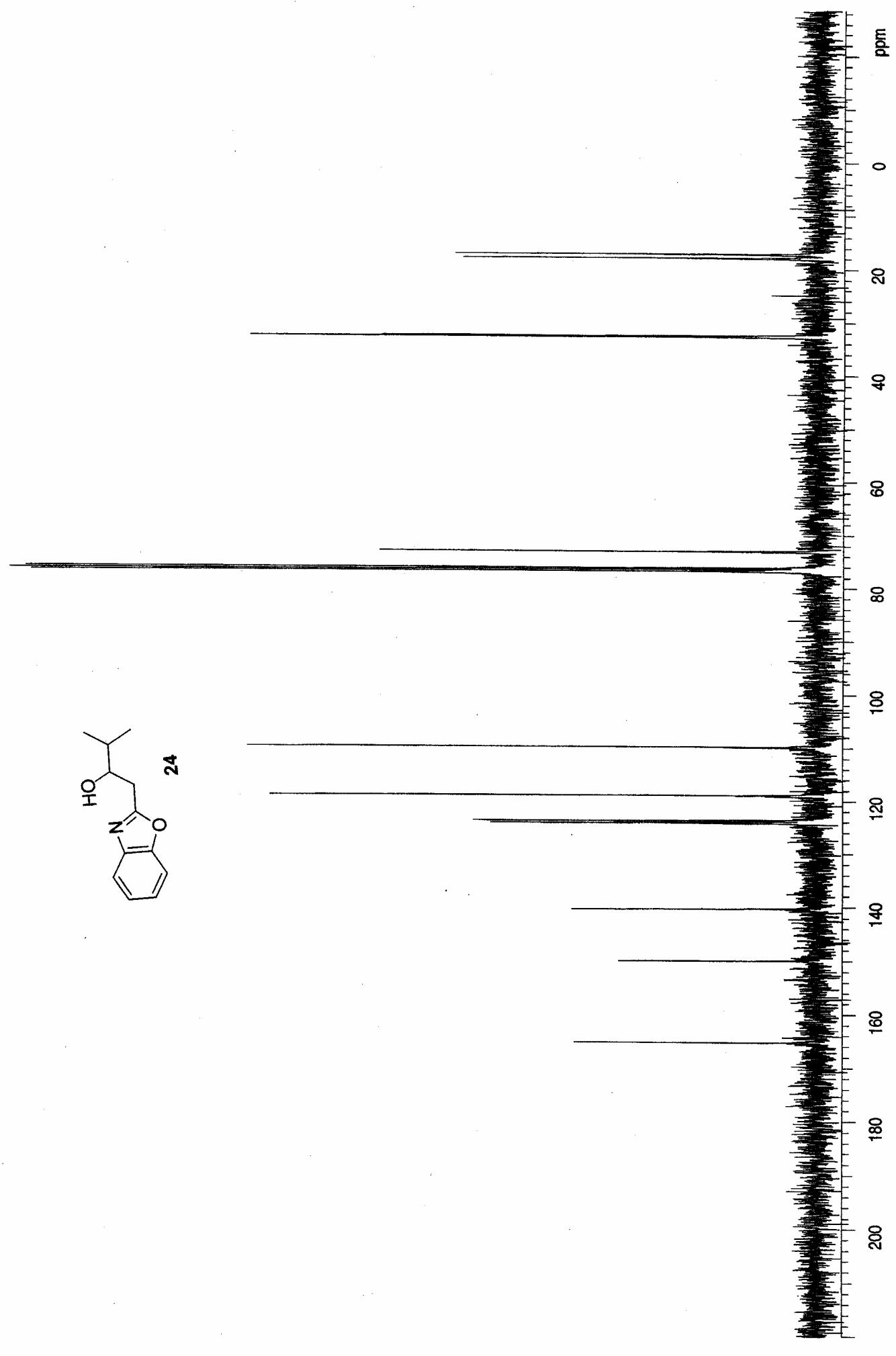




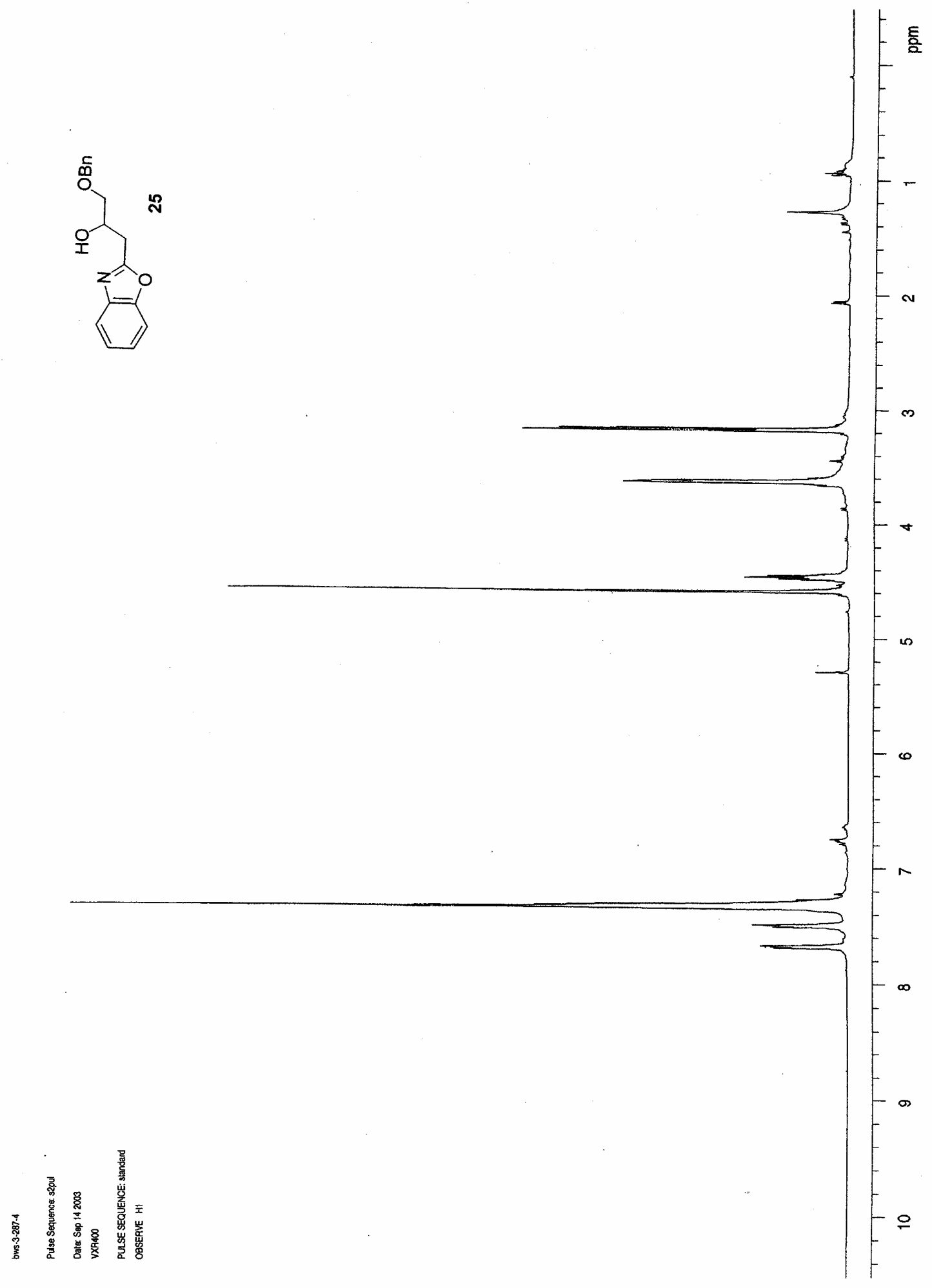




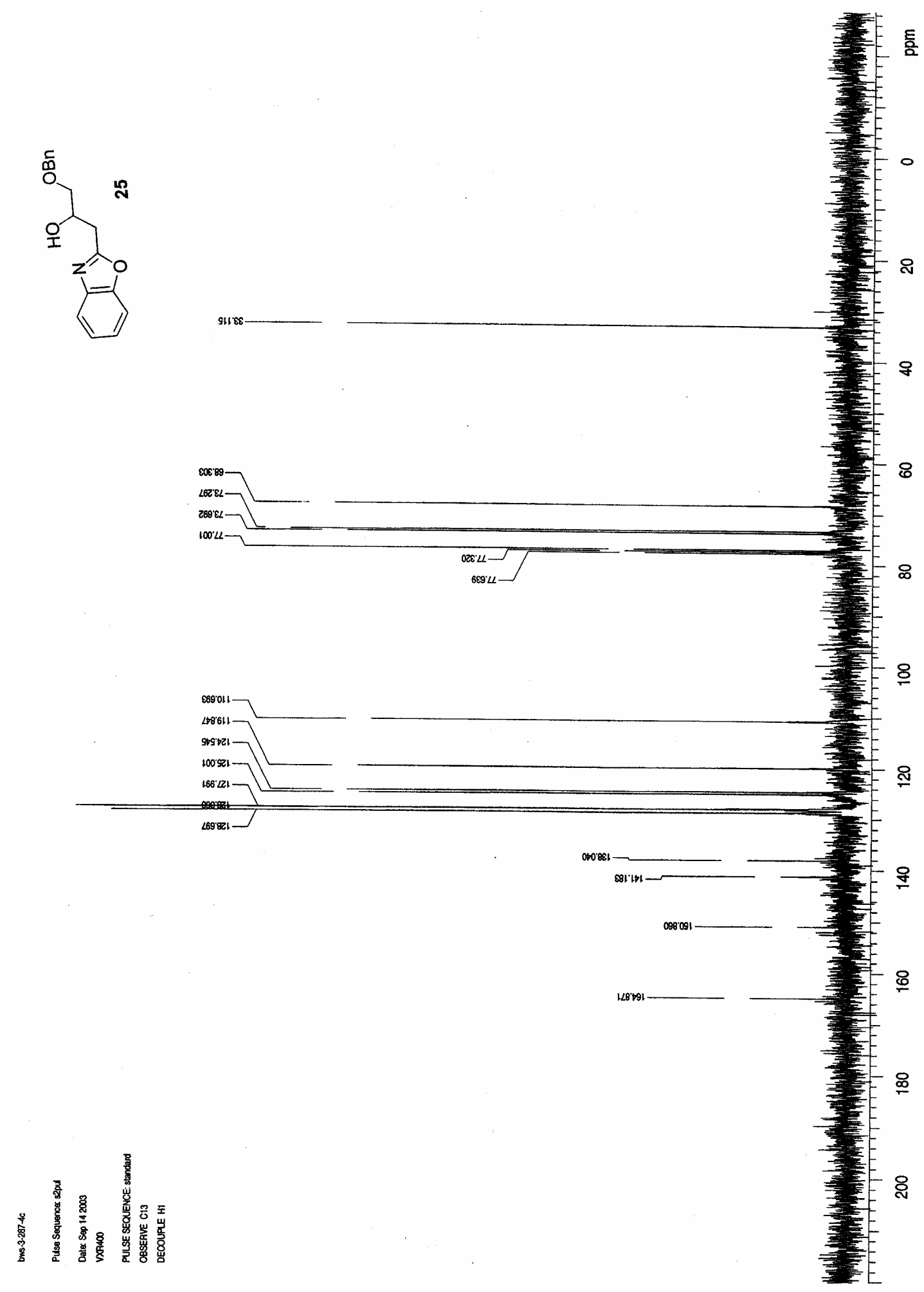




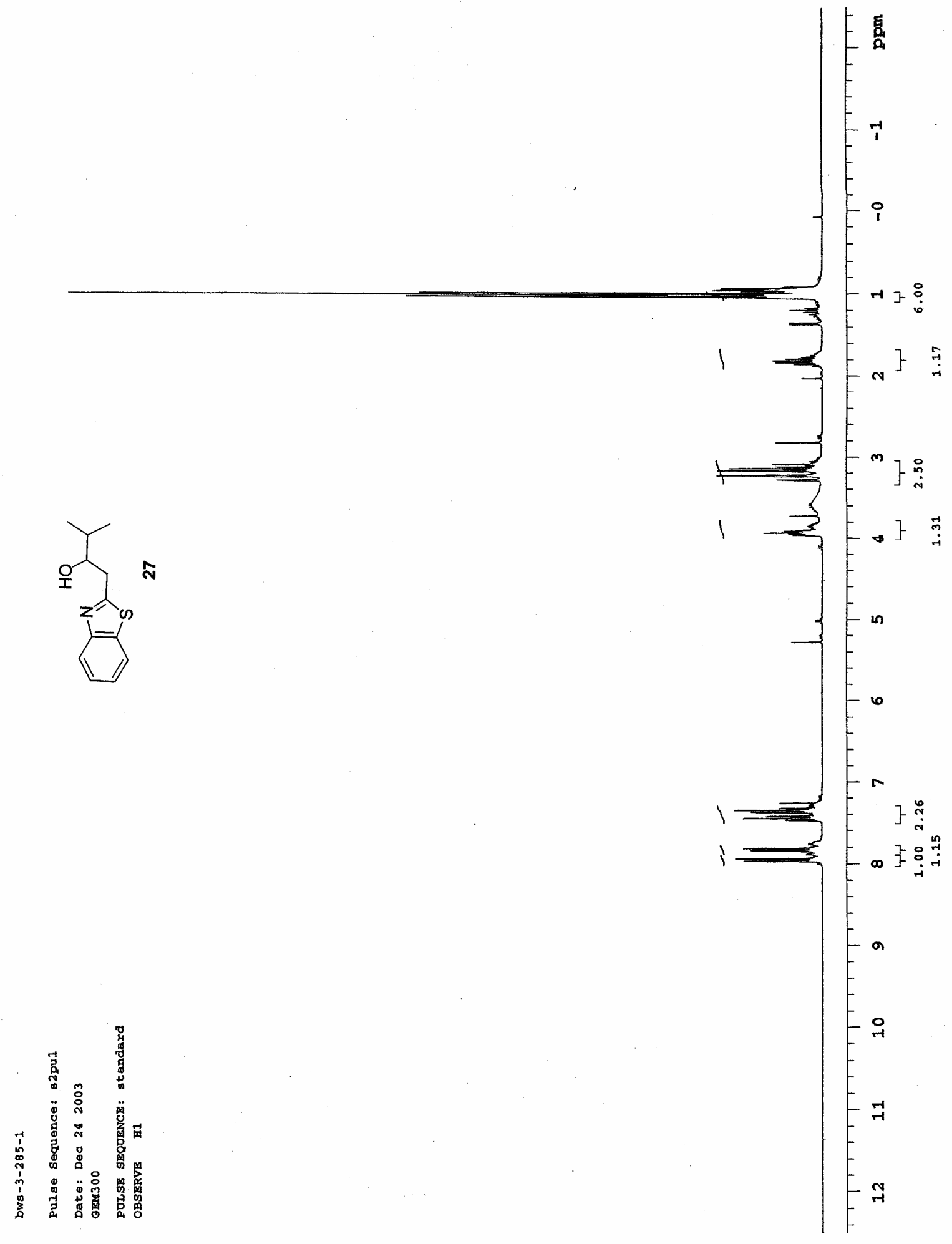




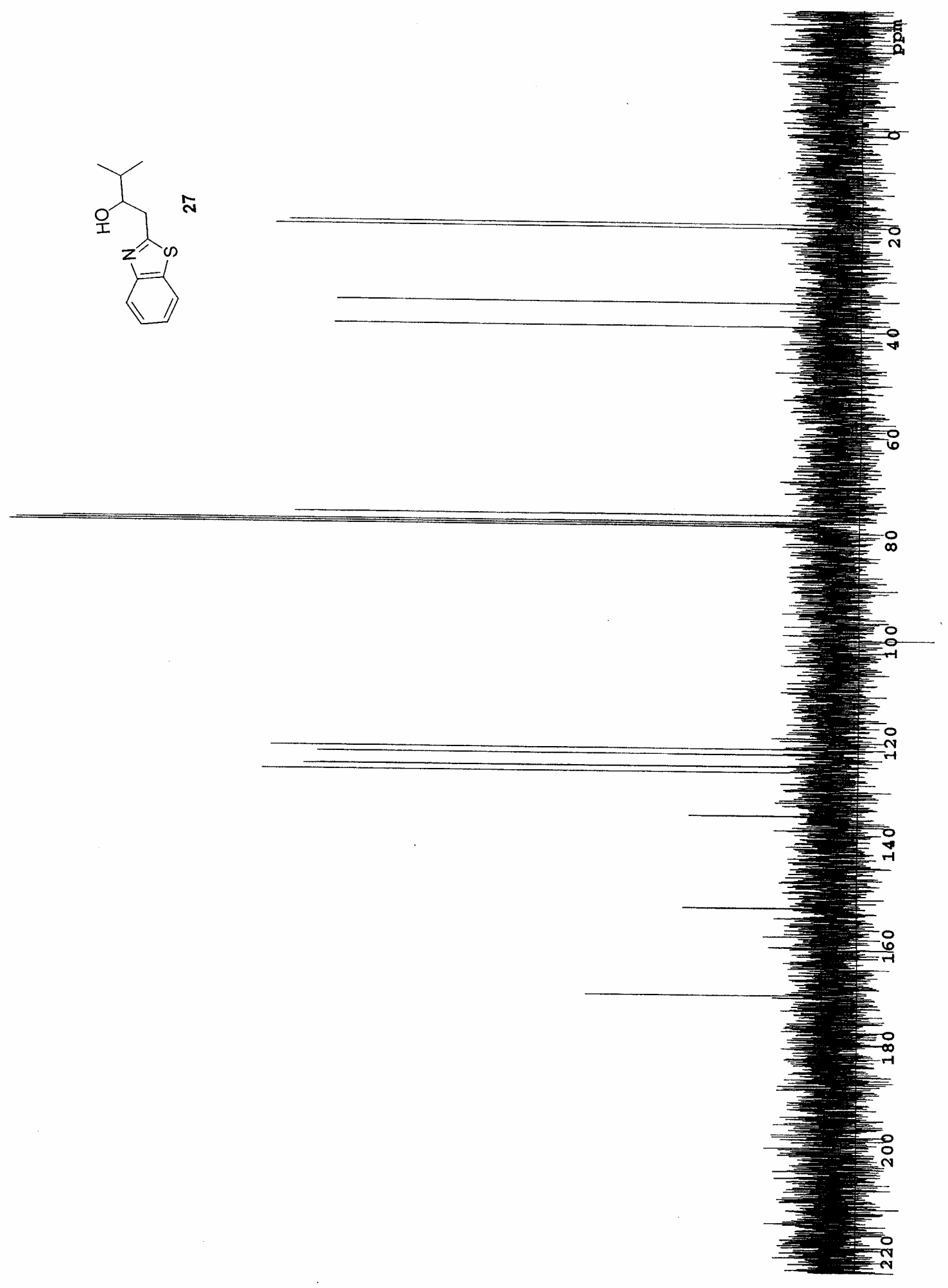

S-35 


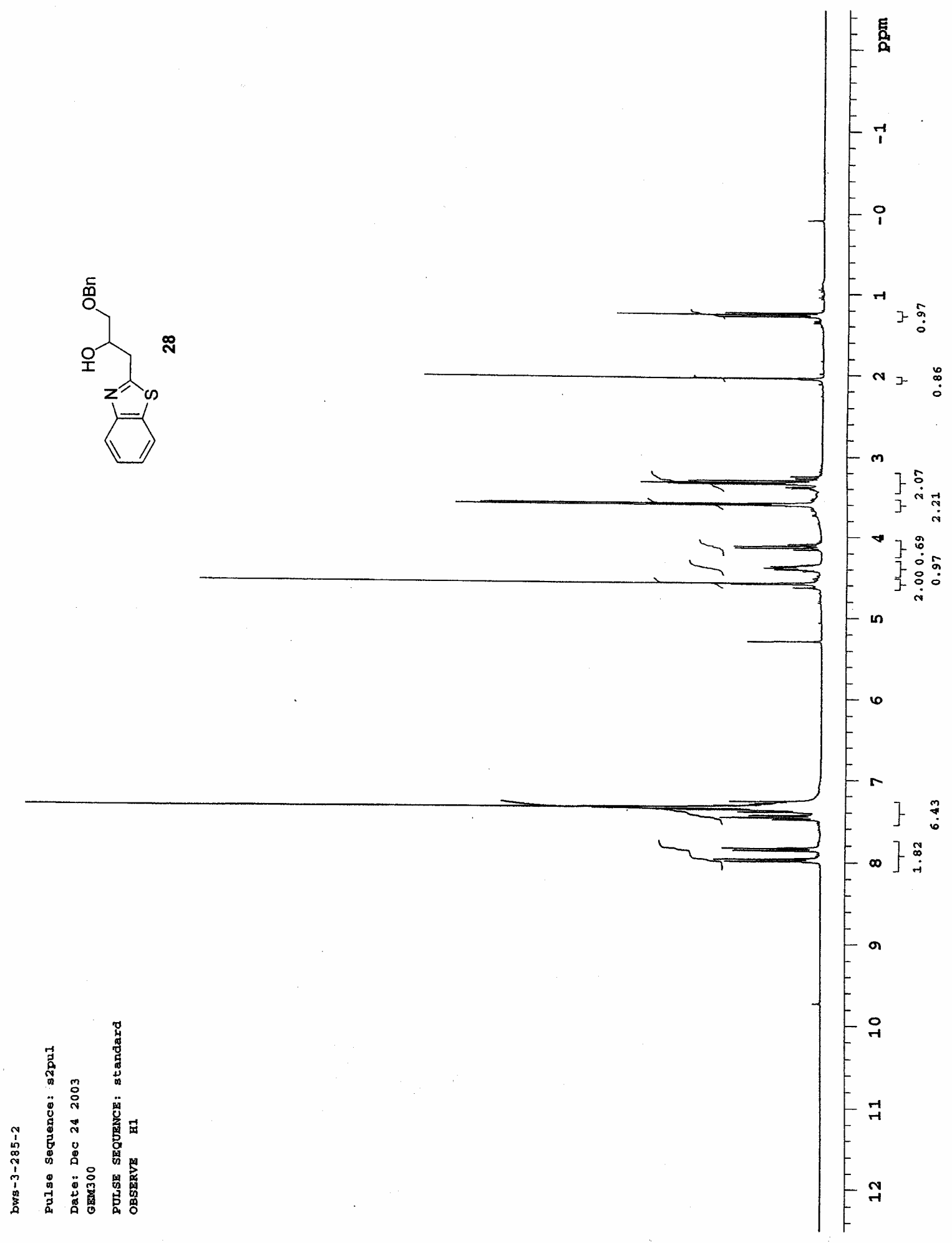




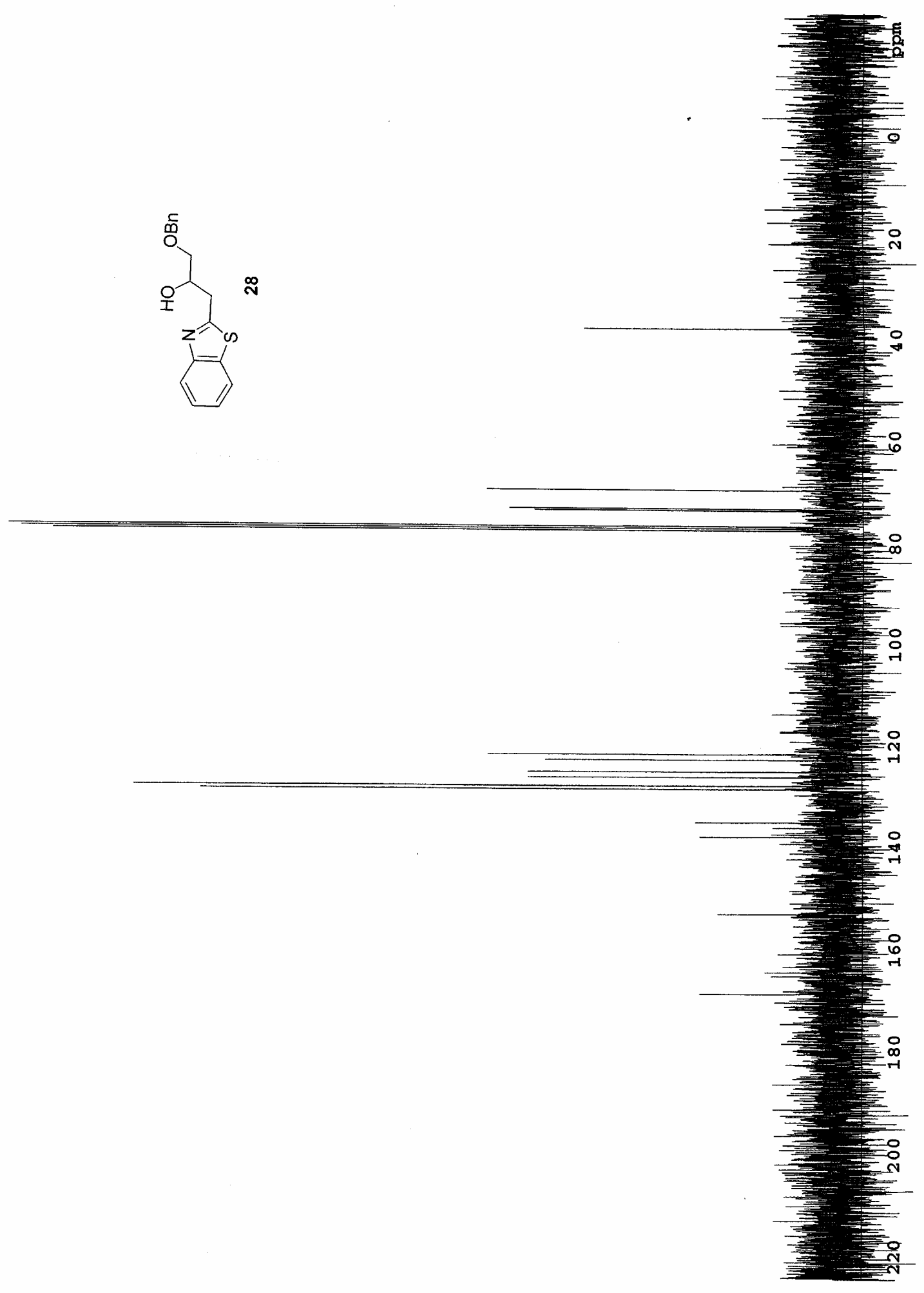




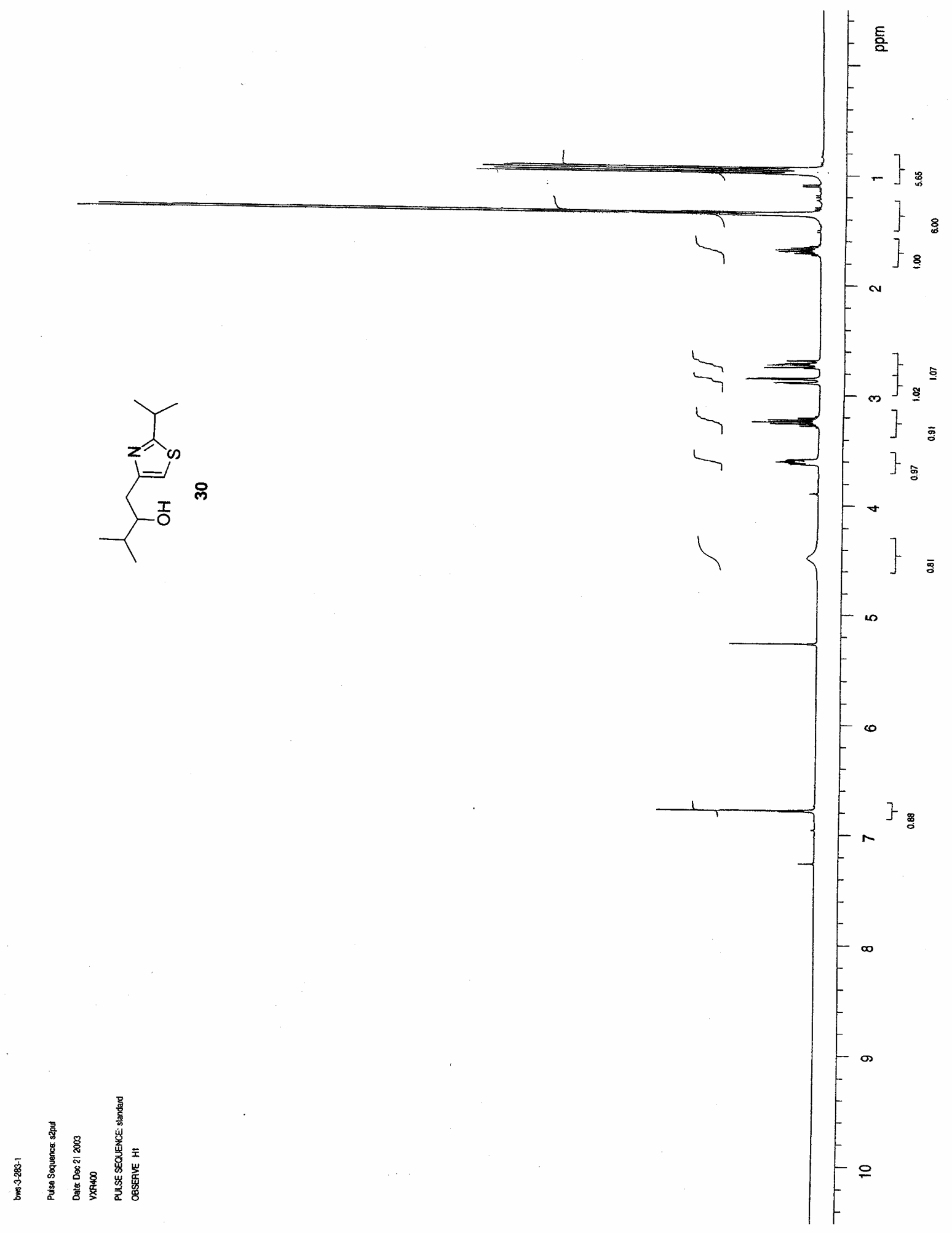




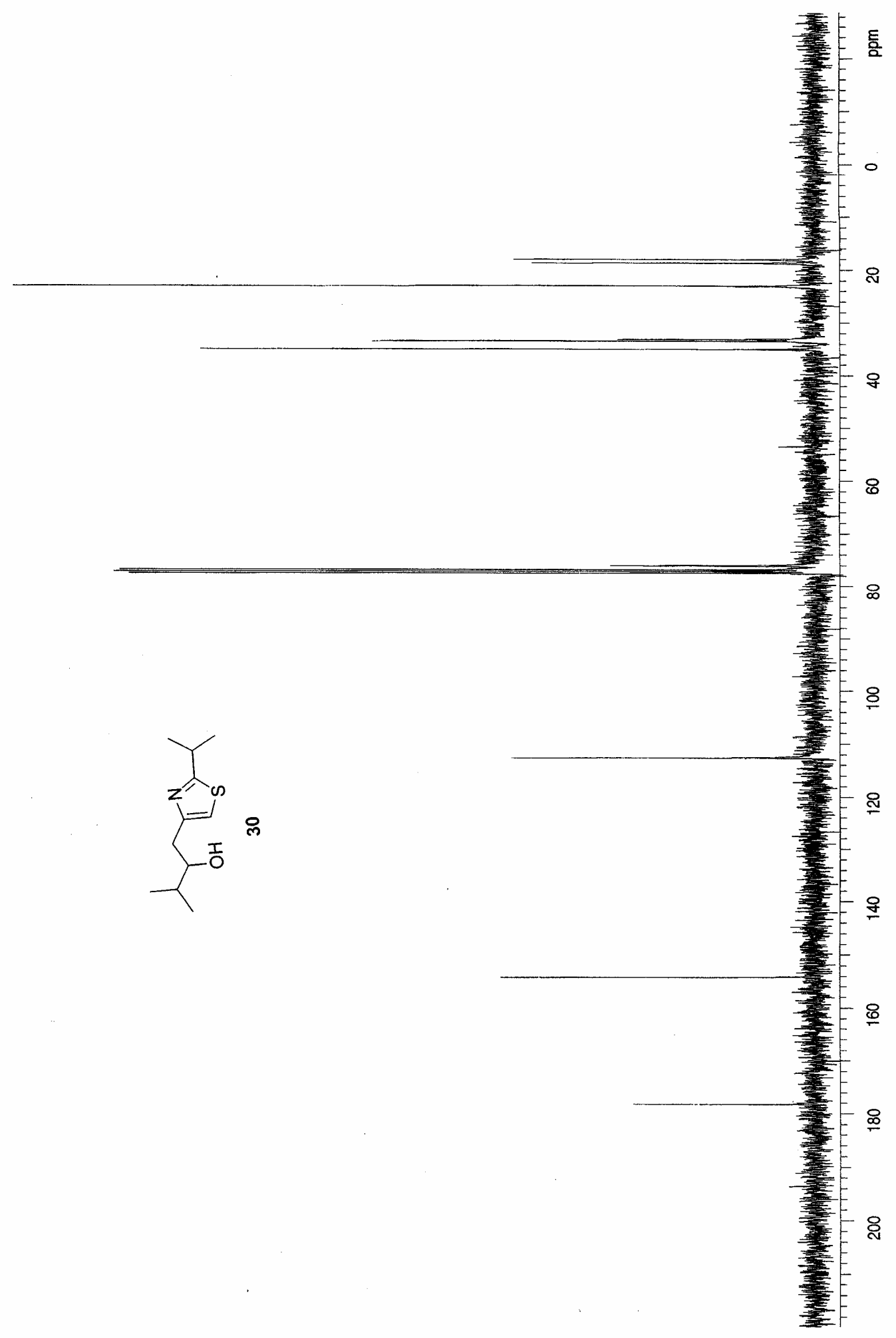




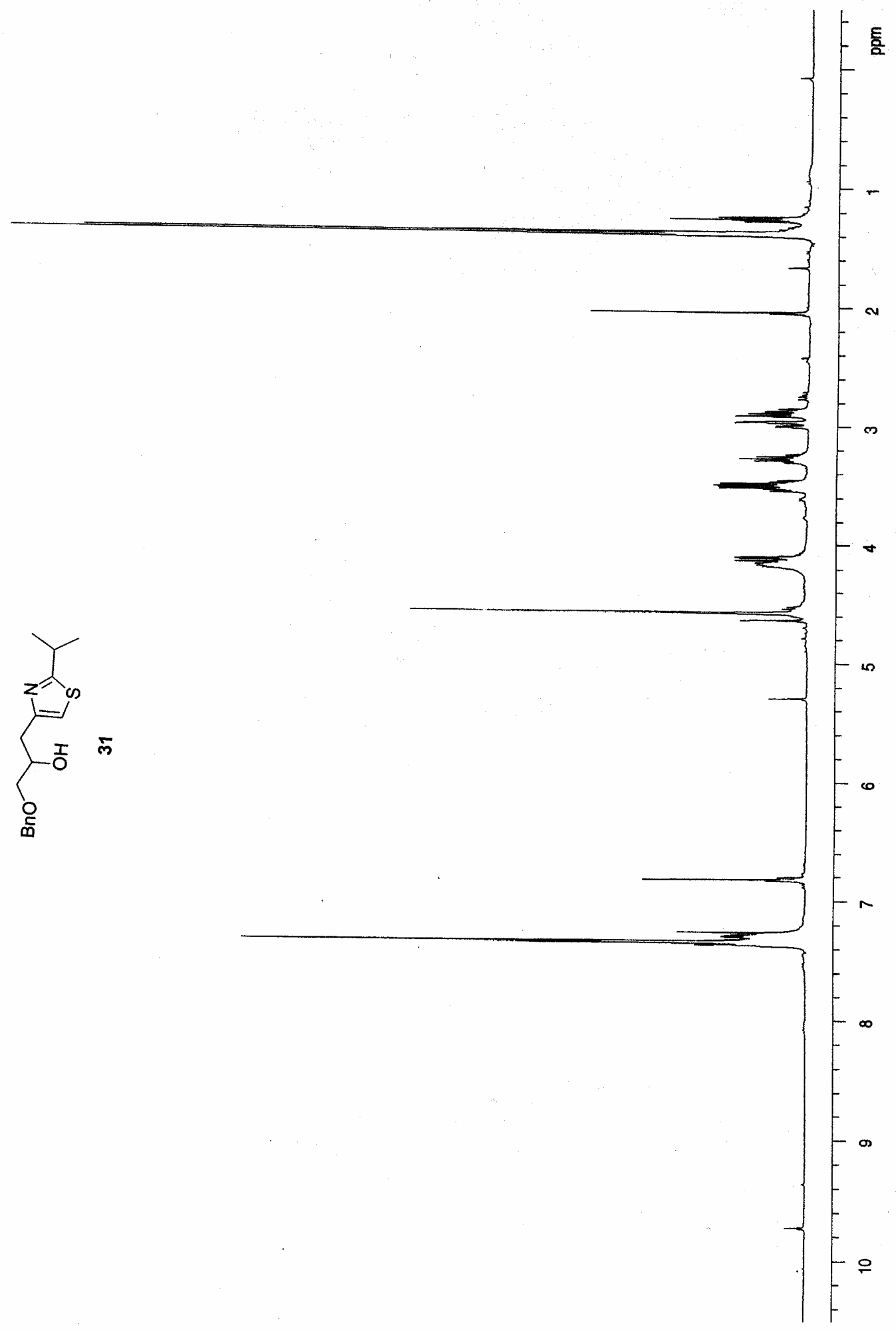




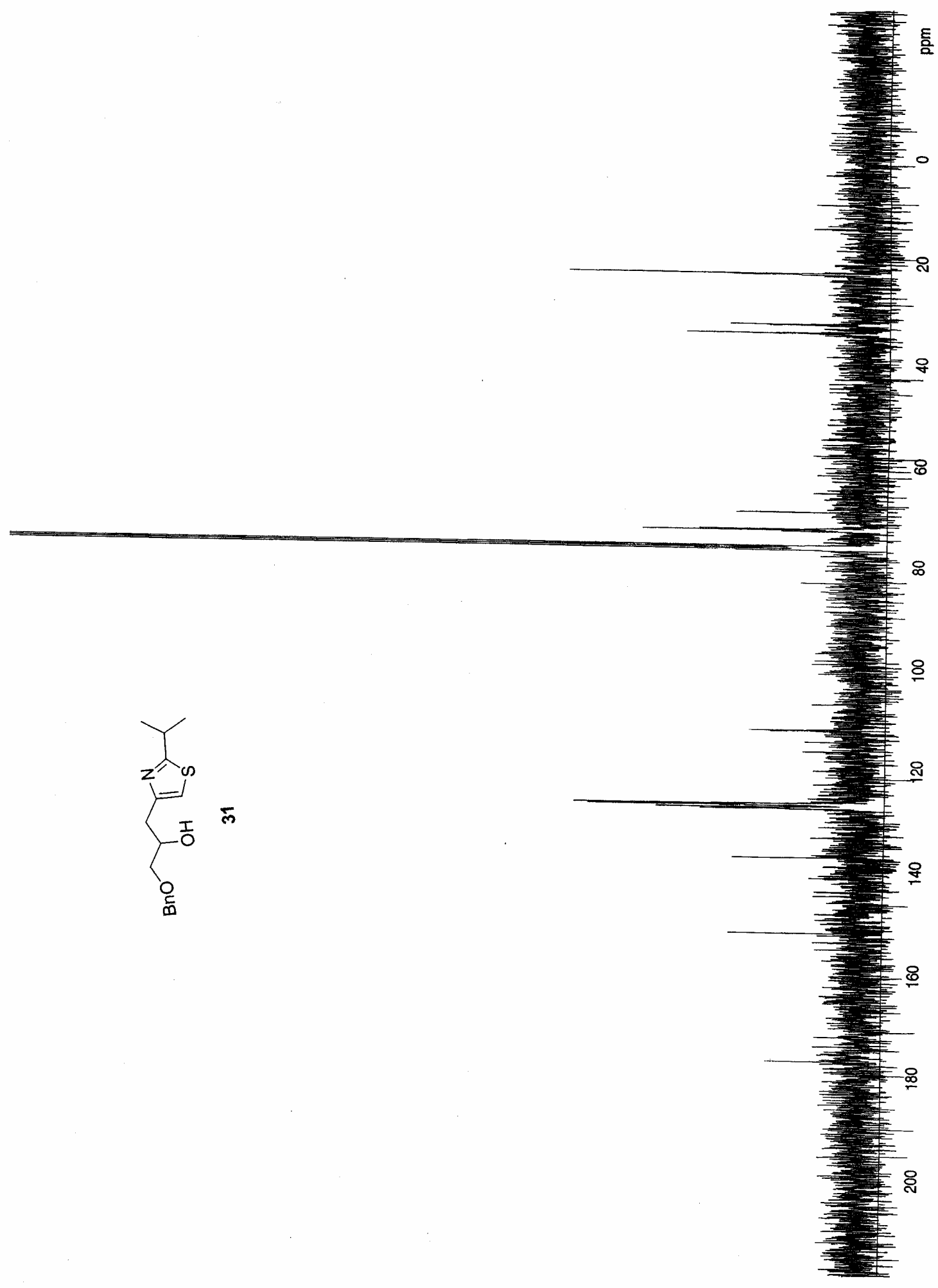




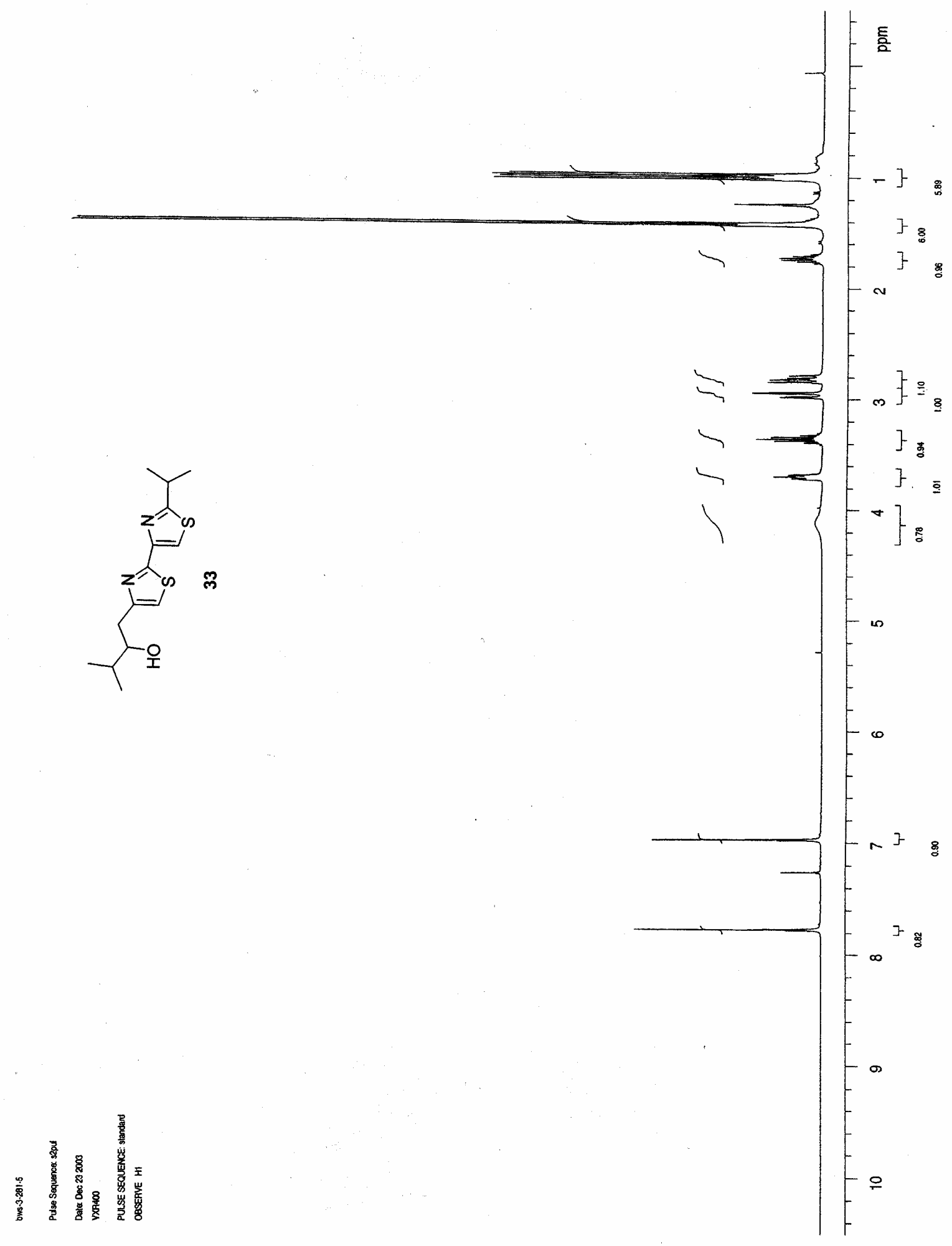




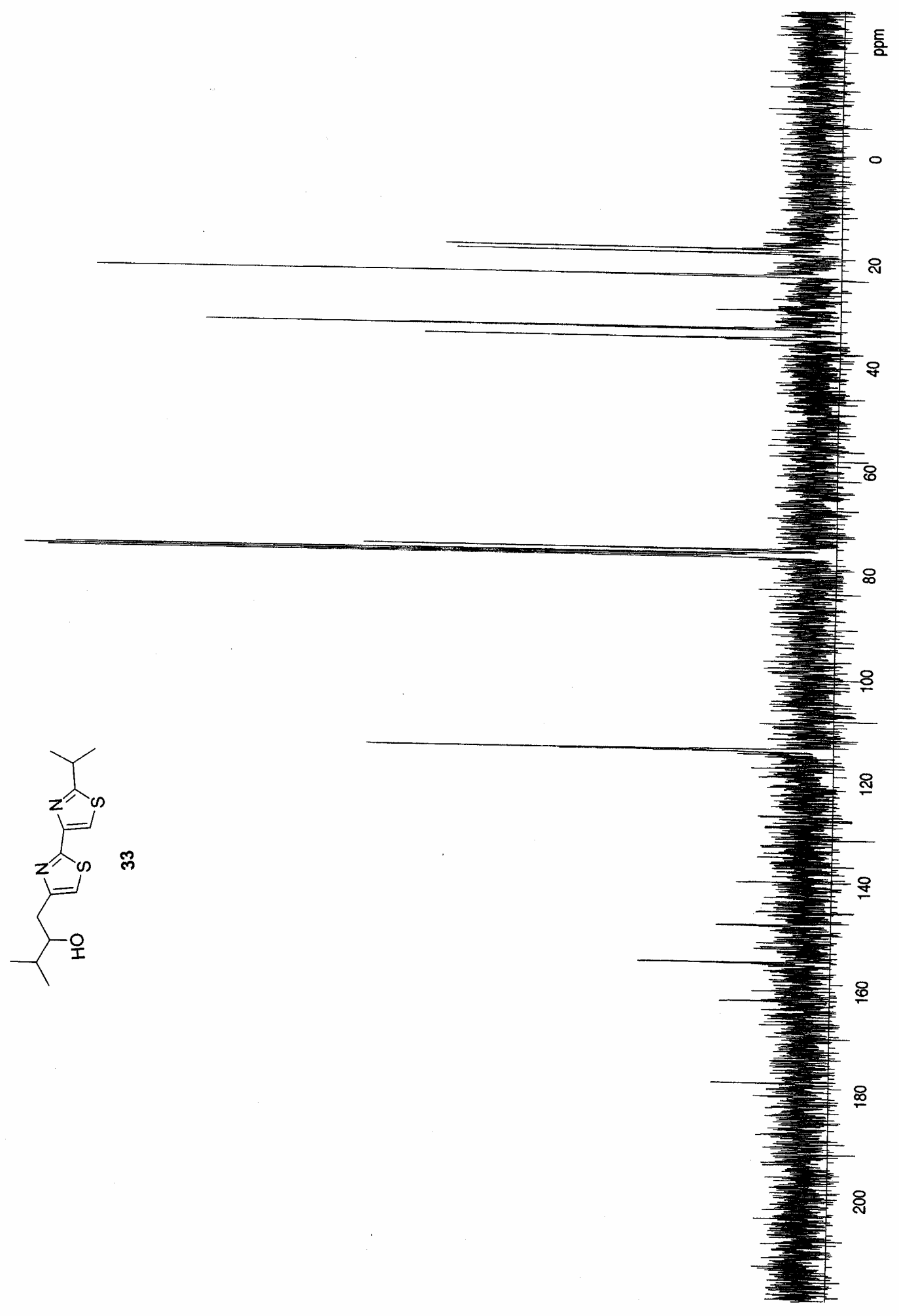




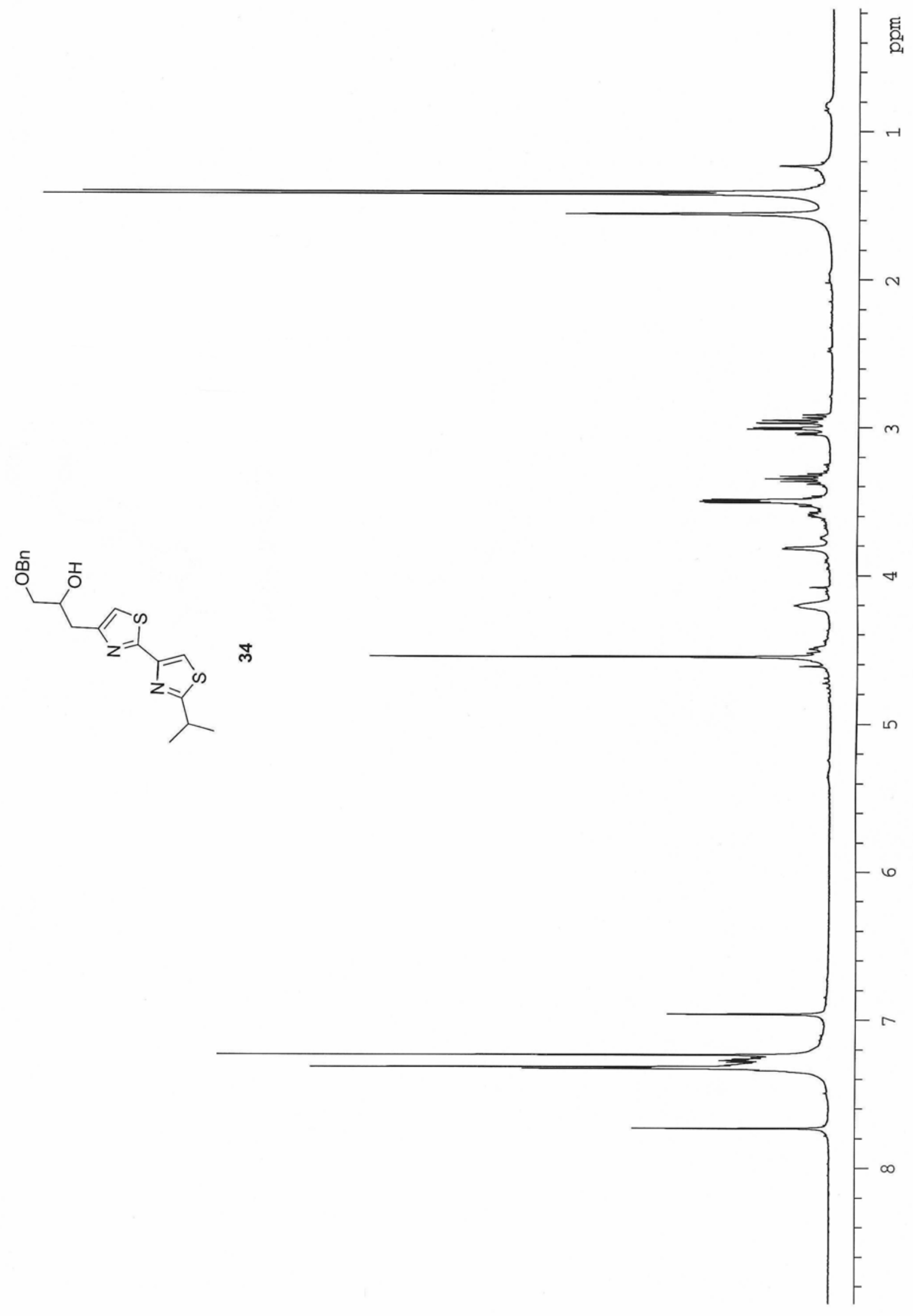




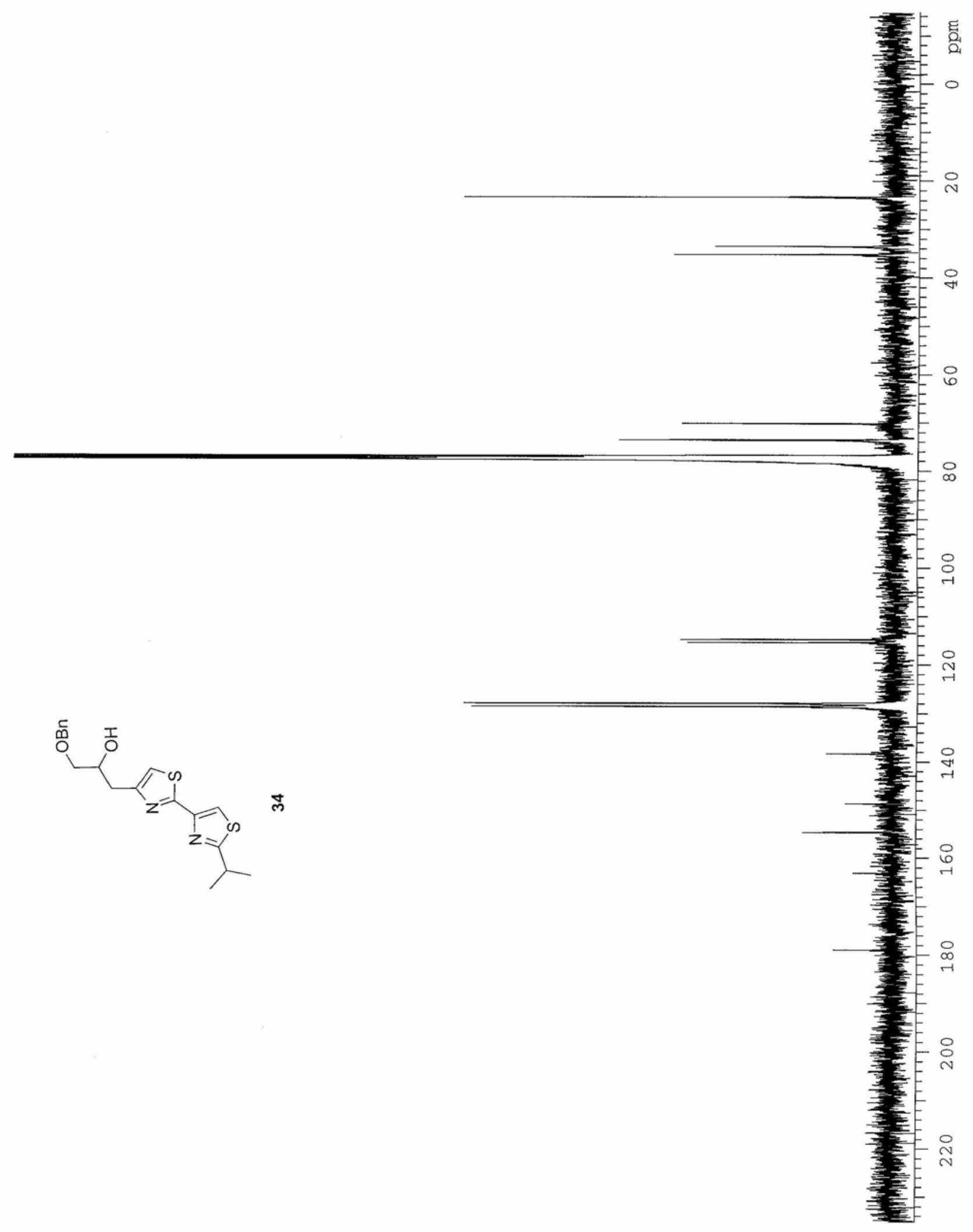




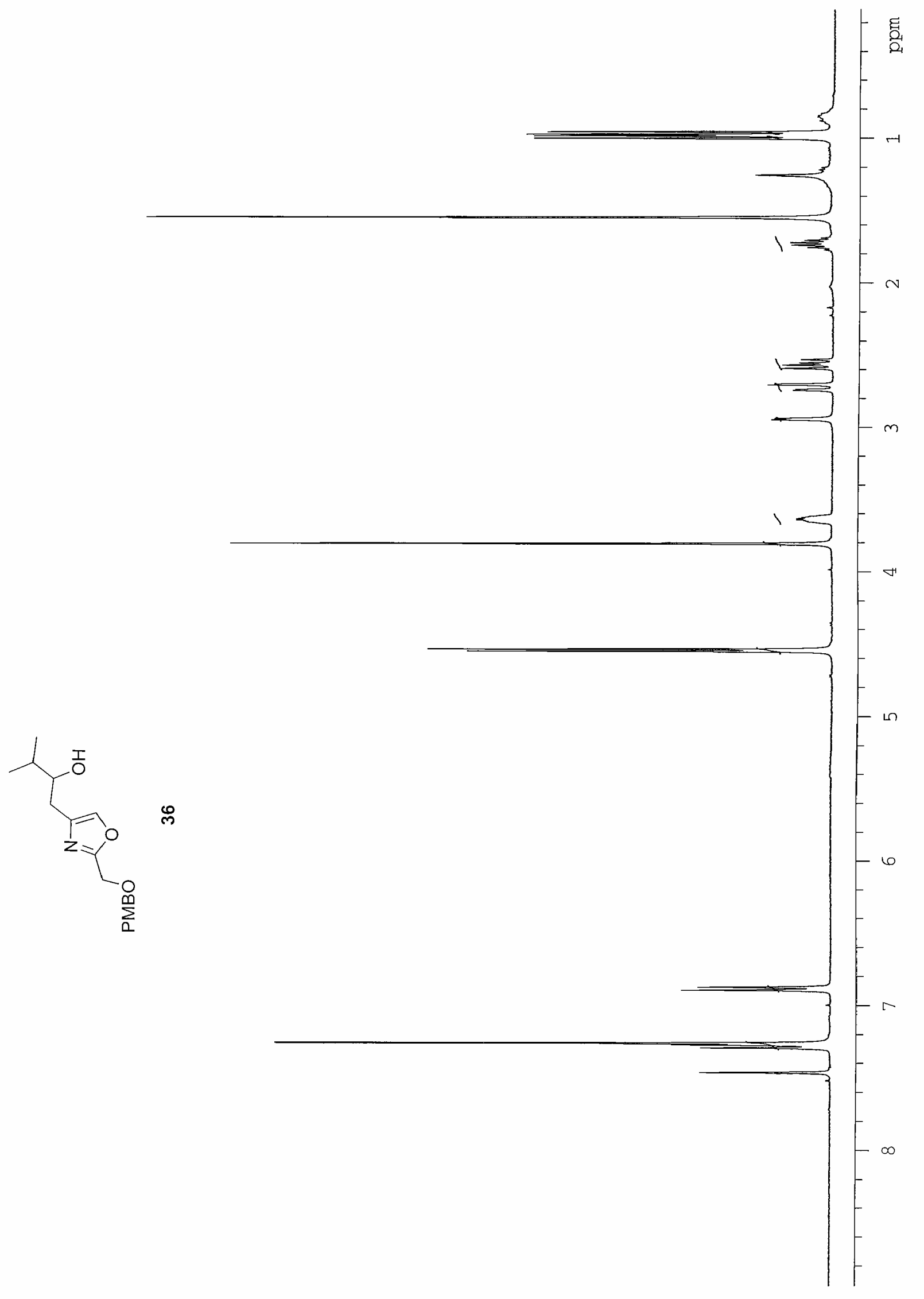




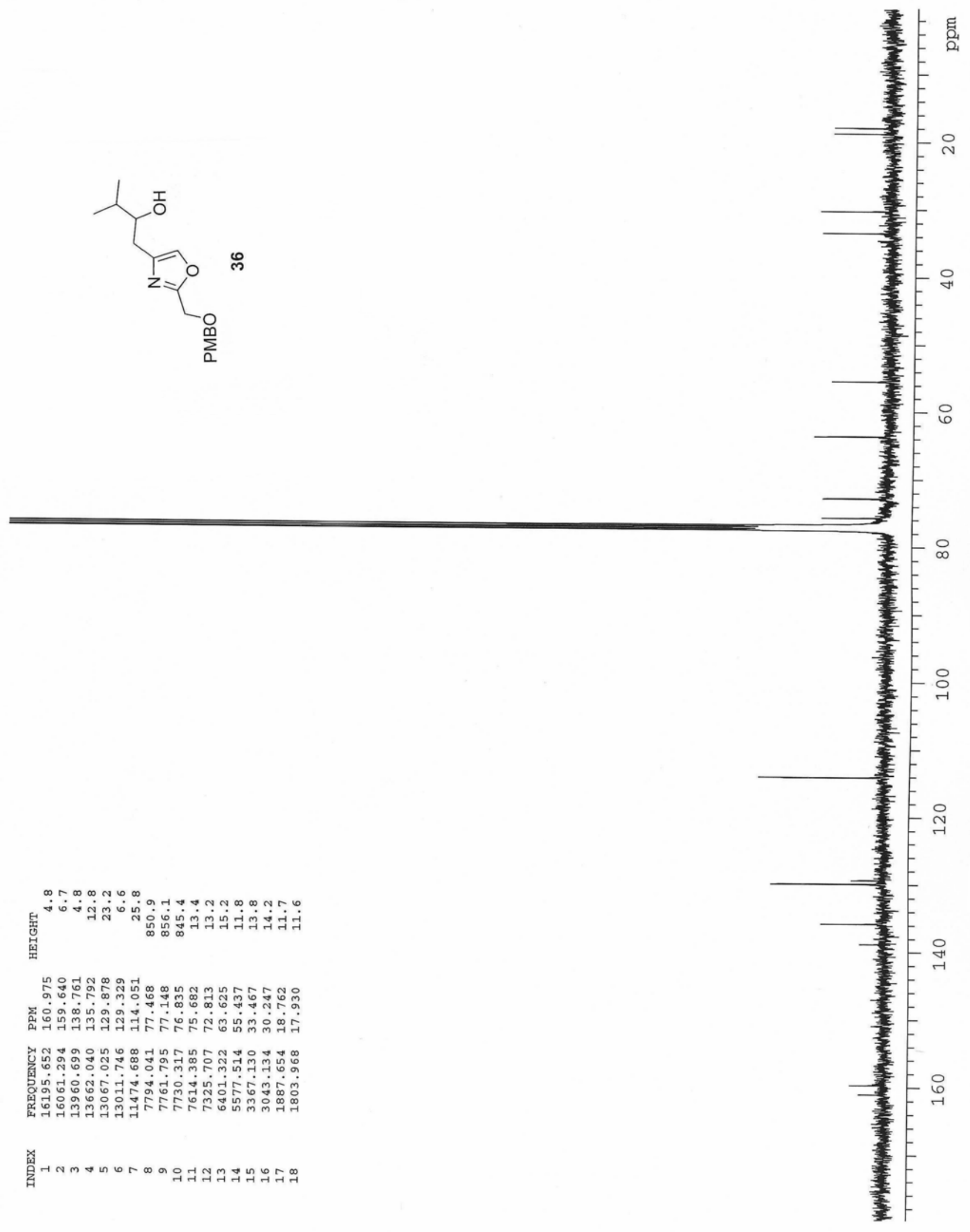

